\title{
Menus of contracts determine sorting patterns
}

Citation for published version (APA):

Bernard, M., Dohmen, T., Non, A., \& Rohde, I. M. T. (2019). Menus of contracts determine sorting patterns. Journal of Economic Psychology, 72, 293-311. https://doi.org/10.1016/j.joep.2019.04.004

Document status and date:

Published: 01/06/2019

DOI:

10.1016/j.joep.2019.04.004

Document Version:

Publisher's PDF, also known as Version of record

Document license:

Taverne

\section{Please check the document version of this publication:}

- A submitted manuscript is the version of the article upon submission and before peer-review. There can be important differences between the submitted version and the official published version of record.

People interested in the research are advised to contact the author for the final version of the publication, or visit the DOI to the publisher's website.

- The final author version and the galley proof are versions of the publication after peer review.

- The final published version features the final layout of the paper including the volume, issue and page numbers.

Link to publication

\footnotetext{
General rights rights.

- You may freely distribute the URL identifying the publication in the public portal. please follow below link for the End User Agreement:

www.umlib.nl/taverne-license

Take down policy

If you believe that this document breaches copyright please contact us at:

repository@maastrichtuniversity.nl

providing details and we will investigate your claim.
}

Copyright and moral rights for the publications made accessible in the public portal are retained by the authors and/or other copyright owners and it is a condition of accessing publications that users recognise and abide by the legal requirements associated with these

- Users may download and print one copy of any publication from the public portal for the purpose of private study or research.

- You may not further distribute the material or use it for any profit-making activity or commercial gain

If the publication is distributed under the terms of Article $25 \mathrm{fa}$ of the Dutch Copyright Act, indicated by the "Taverne" license above, 


\title{
Menus of contracts determine sorting patterns
}

\author{
Mark Bernard ${ }^{\mathrm{a}}$, Thomas Dohmen ${ }^{\mathrm{b}}$, Arjan Non ${ }^{\mathrm{c}}$, Ingrid M.T. Rohde ${ }^{\mathrm{d}, *}$ \\ ${ }^{a}$ Swedish Competition Authority, Stockholm, Sweden \\ ${ }^{\mathrm{b}}$ University of Bonn, IZA, Germany, and Maastricht University the Netherlands \\ ${ }^{\mathrm{c}}$ Maastricht University the Netherlands and CESifo, Germany \\ ${ }^{\mathrm{d}}$ University of Bonn, Germany
}

\section{A R T I C L E I N F O}

\section{JEL classification:}

C91

D81

D82

J16

J31

\section{Keywords:}

Incentives

Multidimensional sorting

Lab experiment

\begin{abstract}
A B S T R A C T
Using a real-effort task laboratory experiment, we investigate how the menu of available contracts affects worker self-selection into pay-for-performance contracts based on characteristics such as productivity and risk attitude. We provide evidence that the same contract attracts different types of workers for different sets of available alternatives. This insight, which is consistent with theoretical considerations, is crucial for organizations, because the type of workers that is attracted by a given incentive contract depends on the contracts offered by competing firms. Moreover, available alternative contracts determine the scope of worker types that can be attracted with a particular contract. Another implication is that organizations can design menus of contracts to induce fine-tuned multidimensional sorting patterns, which facilitates optimal assignment of workers to tasks.
\end{abstract}

\section{Introduction}

Apart from providing incentives to workers, an important reason for paying employees on the basis of their performance is to attract worker types that contribute to an organization's success. As an organization's performance depends on the characteristics of its workforce, attracting workers with the best-fitting bundle of skills, preferences, and personality traits is an essential challenge. Previous studies provide abundant evidence that performance-based pay schemes induce self-selection of more productive workers. In particular, payment schemes such as piece rate contracts and budget-based compensation plans are found to attract productive workers, as are payment schemes that reward relative performance, such as promotion tournaments. Prominent examples of the former are Chow (1983), Waller and Chow (1985), Shields and Waller (1988), Lazear (2000), Cadsby, Song, and Tapon (2007), and Kachelmeier and Williamson (2010); while Dohmen and Falk (2011) also document productivity sorting into relative performance schemes. ${ }^{1}$

These sorting effects are not confined to individuals' productivity, but extend to other dimensions that are potentially relevant for organizational performance. Various studies have provided evidence that relatively risk-averse individuals are more likely to sort into relatively safe payment schemes (e.g. Cable \& Judge, 1994; Eriksson, Teyssier, \& Villeval, 2009; Bellemare \& Shearer, 2010; Dohmen and Falk, 2010, 2011). Likewise, Niederle and Vesterlund (2007) argue that gender differences in competitiveness affect the choice between tournaments and piece rates, and Larkin and Leider (2012) demonstrate that overconfident workers feel attracted to more

\footnotetext{
* Corresponding author.

E-mail addresses: mark.bernard@kkv.se (M. Bernard), t.dohmen@uni-bonn.de (T. Dohmen), j.non@maastrichtuniversity.nl (A. Non), i.rohde@uni-bonn.de (I.M.T. Rohde).

${ }^{1}$ Other examples are Farh, Griffeth, and Balkin (1991), Barro and Beaulieu (2003), Eriksson and Villeval (2008), Guiteras and Jack (2014), Hales, Wang, and Williamson (2014), and Bäker and Mertins (2013).
} 
ambitious pay-for-performance contracts.

All of these studies investigate sorting effects in situations where individuals have the choice between a pay-for-performance scheme and one alternative contract, typically a fixed payment. By design, these settings are not suited to demonstrate that the sorting effects of a particular contract crucially depend on the available alternatives that workers face. Our paper fills this gap by explicitly examining, using a within-subjects design, how the selection effects induced by a particular contract depend on the available alternatives. We conduct a laboratory experiment, as lab experiments allow us to overcome several limitations of naturally occurring data. ${ }^{2}$

Our study builds on the experimental design of Dohmen and Falk (2011), where participants could choose between a fixed payment and a variable payment contract before performing a real effort task. Participants were assigned to one treatment condition. The variable payment scheme varied across treatment conditions. It was either a piece rate, a tournament or a revenue-sharing scheme. ${ }^{3}$ In our experiment, by contrast, each participant makes a series of choices between remuneration schemes in four different environments. In particular, participants choose (i) between a fixed payment and a piece rate, (ii) between a fixed payment and a tournament, (iii) between a piece rate and a tournament, and (iv) between all three contracts. This within-subjects design allows us to assess how sensitive sorting patterns are to variations in the menu of contracts. Specifically, our within-subjects design allows us to identify the characteristics of individuals whose preferred contract type changes with the menu of alternatives. ${ }^{4}$

We find that the contractual environment crucially affects multidimensional sorting patterns: a given payment scheme attracts different worker types when the alternatives change. For instance, a given piece-rate contract in our experiment attracts workers with higher average productivity when the alternative contract stipulates a fixed payment, than when the alternative contract specifies a tournament. At the same time, the piece-rate contract attracts relatively risk-averse workers when the alternative contract is a tournament compared to the environment in which the alternative contract entails a fixed payment. An immediate implication of this result is that a particular incentive contract has different effects on performance in sectors or industries that differ with respect to the menu of contracts offered. Likewise, the composition of a firm's workforce is likely to change if competitors change their incentive schemes. As a straightforward example, consider a firm that offers a piece-rate contract. If its competitors offer a fixed-wage contract, the piece rate might attract the most productive workers. But if the competitors switch to a tournament scheme, average productivity at the piece-rate firm is likely to decline. Hence, organizations have to take the menu of alternative contracts that competitors offer to potential applicants into account when designing their own incentive scheme. ${ }^{5}$

Another implication of our findings is that firms can induce fine-tuned multidimensional sorting patterns within their organization by offering a menu of contracts. This allows firms to sort workers appropriately to different tasks that require different bundles of characteristics. Previous studies have documented that variable pay schemes, such as tournaments and piece-rate contracts, attract productive workers who are relatively willing to take risks when the only alternative is a fixed-payment contract (see Cable \& Judge, 1994, Cadsby et al., 2007, and Dohmen \& Falk, 2011). We show, however, that the sorting dimensions "productivity" and "risk attitude" can be decoupled by offering a menu of contracts. This is important, as organizations might want to attract highly productive but risk-averse workers. For example, consider a multidivisional organization that offers traineeships to recent university graduates. Such an organization may want to allocate highly productive risk-averse workers to divisions where small mistakes have severe negative consequences on output, but at the same time it may want to assign highly productive workers who are relatively willing to take risks to divisions where mistakes are less harmful and where risk-taking fosters innovation. If productivity and risk preferences are not easily observed during the traineeship, a fairly simple menu of piece-rate, fixed-payment and tournament contracts could serve as a screening device to sort trainees into jobs that best fit their characteristics.

The paper is organized as follows. The next section discusses hypotheses and describes the experimental design and procedures. Next, we present the results in three steps: first, we show how productivity, relative self-assessment, and personality traits and preferences such as gender and risk attitudes affect sorting into contracts. We then establish our main result, namely that the type of workers attracted by a particular contract crucially depends on the alternatives offered. Thereafter, we show that we can induce more refined sorting patterns by extending the menu of contracts. We conclude by discussing various implications of our results.

\section{Hypotheses and design of the experiment}

We first present an overview of our experimental design and derive our main hypotheses. Thereafter, we discuss the design of our experiment stage-by-stage and provide all procedural details.

\footnotetext{
${ }^{2}$ Specifically, to study our research question, we need (i) accurate measures of individuals' productivity, preferences, and personality traits; (ii) detailed information about the menu of contracts that individuals can choose from when making their decision; (iii) exogenous changes in the menu of contractual arrangements. Naturally occurring data typically do not have these properties, while the controlled lab environment is perfectly suited to generate such data. See Dohmen and Falk (2011) for a more extensive discussion.

${ }^{3}$ The contracts represent stylized versions of real-world contracts, such as fixed wages without clear career prospects (fixed wage), up-or-out promotion schemes (tournament) and sales commissions (piece rates).

${ }^{4}$ We deliberately abstain from analyzing the incentive effects of the different payment schemes, as there is a large literature that documents these effects for tournaments (e.g., Bull, Schotter, \& Weigelt, 1987), Schotter \& Weigelt, 1992; Knoeber \& Thurman, 1994; Bognanno, 2001; Falk \& Fehr, 2002) and piece rates (e.g., Bull et al., 1987; Van Dijk, Sonnemans, \& Van Winden, 2001 and Stajkovic \& Luthans, 2001).

${ }^{5}$ There are clearly other factors that affect optimal contract design that we abstract from in this paper, including, for example, monitoring costs (e.g., Stiglitz, 1975), observability of effort or output (e.g., Lazear \& Rosen, 1981), and temporal aspects of incentive contracts (e.g., Laffont \& Tirole, 1988; Baron \& Besanko, 1984; Gibbons, 1987; Kanemoto \& MacLeod, 1992).
} 


\subsection{Setting and hypotheses}

\subsubsection{Key elements of the experimental design}

We design a lab experiment to examine systematically how the sorting effects of a particular contract depend on the available alternatives. Our lab experiment builds on the framework developed by Dohmen and Falk (2011), henceforth "DF". The core of the experiment are individuals' choices on how they want to be rewarded for a real-effort task. The task is to multiply one-digit numbers by two-digit numbers for $10 \mathrm{~min}$. Before choosing their preferred payment contract, participants perform the task for $5 \mathrm{~min}$ and receive feedback about their individual productivity during that trial, but not their relative productivity. We specify three distinct payment contracts: (1) a fixed payment contract (F), (2) a piece-rate contract (P), and (3) a tournament contract (T).

The three payment schemes are parameterized exactly as in DF. The parametrization is chosen in such a way that a participant of median productivity earns roughly the same amount when opting for piece rates as when he/she chooses the fixed payment. The tournament yields higher potential earnings to compensate for the additional risk. This parameterization ensures that each of the three alternatives is attractive for a substantial number of workers, which facilitates the study of sorting patterns.

In particular, the fixed payment guarantees a payment of 400 points irrespective of the number of correctly solved multiplication problems, i.e.,

$$
\mathrm{W}^{\mathrm{F}}=400 \text {. }
$$

The piece rate pays 10 points for each multiplication problem solved, i.e.,

$$
W_{i}^{P}=10 * x_{i}
$$

where $x_{i}$ is the number of correctly solved multiplication problems by individual $i$.

The tournament contract involves competition among two persons. The contestant who solves more problems in the 10-minute work phase wins the tournament. The winner receives a prize of 1300 points, while the loser receives 0 points. Experimental subjects who opt for the tournament contract are randomly matched with another subject who also chooses the tournament contract. ${ }^{6}$ In sum, when subject $i$ is randomly matched with opponent $j$ (who also opts for the tournament), his or her earnings in the tournament $W_{i}^{T}$ are determined as follows:

$$
W_{i}^{T}=\left\{\begin{array}{c}
1300 \text { if } x_{i}>x_{j} \\
1300 \text { with probability } 0.5 \text { and } 0 \text { with probability } 0.5 \text { if } x_{i}=x_{j} \\
0 \text { if } x_{i}<x_{j}
\end{array}\right.
$$

In order to study how sorting into payment schemes depends on the available contract alternatives, we present participants (henceforth "workers") with four different menus of contracts that consist of all possible combinations of the three contracts. The four menus of contracts are: (i) piece rate vs. fixed payment (henceforth "PF"), (ii) tournament vs. fixed payment ("TF"), (iii) piece rate vs. tournament ("PT") and (iv) piece rate vs. tournament vs. fixed payment ("PTF"). These four menus of contracts are offered to workers sequentially, one at a time and in random order of presentation. We further measure workers' risk attitudes, productivity (the amount of problems they can solve in a given amount of time), and relative self-assessment (how they believe they rank in terms of productivity compared to all other workers on the same contract) as potential sorting dimensions, since these characteristics presumably are crucial determinants of the benefits workers expect to derive from each of the different payment schemes, especially the variablepayment ones.

\subsubsection{Hypotheses}

Our analytical framework is subjective expected utility theory (Savage, 1954). Workers compare the expected utility of the available alternatives, and choose the alternative, which provides highest expected utility. To worker $i$, a given contract $k$ yields (subjective) expected utility

$$
E\left(U_{i k}\right)=\sum_{y \in Y_{k}} P_{i k}(y) u_{i}(y)
$$

where $Y_{k}$ is the set of possible monetary outcomes for contract type $k, P_{i k}(y)$ the worker's subjective probability that outcome $y \in Y_{k}$ is realized when choosing contract $k$, and $u_{i}(y)$ the worker's utility function mapping monetary outcomes into utility. Sorting (i.e. selfselection) occurs when contracts systematically generate different utility to different workers, depending on their risk preferences, productivity, or relative self-assessment. These potential sorting dimensions map into the theoretical framework: Risk aversion is captured by a concave curvature of $u_{i}(y)$, while productivity and relative self-assessment shape $P_{i k}$ to different degrees, depending on the characteristics of the contract. For the fixed wage, $Y_{k}=\{400\}$, so the probability $P_{i k}(400)=1$. For the piece rate, $Y_{k}=\{0,10$, $20, \ldots \infty\}$, as all multiples of 10 are theoretically possible, but which outcomes are most likely depends on the worker's beliefs about her own productivity, captured by $P_{i k}(y)$. For the tournament, finally, $Y_{k}=\{0,1300\}$ and $P_{i k}(y)$ is determined by the worker's

\footnotetext{
${ }^{6}$ In case only one subject chooses the tournament contract (which did not happen), the tournament does not take place and the subject receives the fixed payment of 400 points. If there is an odd number of subjects opting for the tournament, one randomly chosen tournament participant's output is used a second time to determine the earnings of the unmatched subject.
} 
relative self-assessment and beliefs about what other workers select into the tournament. ${ }^{7}$

These contracts yield different expected utility to different workers. The piece-rate contract is inherently more attractive the more productive a worker is, as earnings are linearly increasing in productivity. Risk attitudes matter to the extent that workers are unsure about their individual performance. The tournament contract will be considered more attractive the higher workers' relative selfassessment, and consequently the higher their expectation of winning the tournament is. To the extent that relative self-assessment is correlated with actual productivity, the tournament contract attracts more productive workers. If relative self-assessment is uncorrelated with the actual productivity ranking, the tournament attracts predominately overconfident workers. Moreover, tournament participation depends on risk preference since the earnings in the tournament are uncertain when the probability of winning is not 1 . Uncertainty about the winning probability arises because own production is not known for sure and particularly because the productivity of the assigned competitor is unknown.

Previous laboratory experiments such as DF report sorting patterns consistent with the expectations discussed above. While these studies assessed what worker types sort into a particular contract for a given alternative, the primary aim of this study is to investigate how the characteristics of people attracted by a particular contract depend on (variation in) the alternative contracts offered. In what follows, we therefore derive hypotheses about how self- selection into a given contract type changes when the menu of alternative contracts is changed. We start with comparisons across different binary menus. Then, we consider what happens when an alternative is added to a given binary menu. We describe sorting patterns by the differences in average productivity and risk attitudes, discussing relative self-assessment as underlying mechanism when applicable.

Comparisons across binary menus We start with a discussion of sorting into the piece-rate contract. As explained above, and as documented in the literature, a piece-rate contract induces strong productivity sorting when the alternative is a fixed-payment contract. All workers who confidently expect to solve more than 40 multiplication tasks in our setup should opt for the piece rate. When the alternative is a tournament, the piece rate contract also attracts workers who are less productive. The reason is that unproductive workers who prefer the fixed payment over the piece rate may prefer the piece rate over the tournament, because with low self-assessment they perceive their chance of winning the tournament too low to yield an expected payoff that exceeds expected earnings on the piece rate contract. Moreover, individuals with low risk tolerance may find the tournament too risky because they find that the possible higher earnings in the tournament do not compensate for the additional risk. Since the tournament is riskier than the fixed wage, the piece rate also attracts less risk-tolerant workers when the alternative is the tournament. In sum, when the alternative is the tournament rather than the fixed wage, the piece rate should attract less productive (Hypothesis H1a) and less risktolerant (H1b) workers.

Turning to the tournament contract, DF show that it induces sorting on productivity, risk attitude and relative self-assessment when paired with a fixed payment contract, When paired with a piece rate contract instead, the expected payoff from the alternative contract is now linearly increasing in productivity and no longer completely risk free (as workers may not be completely sure about their productivity). However, the tournament is clearly the more risky option compared to the piece rate. Since productive workers derive a higher payoff from the piece rate contract than the fixed payment, they may prefer the tournament over the fixed payment and at the same time prefer the piece rate over the tournament. As a result, the tournament attracts less productive workers when the alternative is the piece rate than when the alternative is the fixed payment $(\mathrm{H} 2 \mathrm{a}) .{ }^{8}$ Moreover, to the extent that actual productivity and beliefs about winning chances go hand in hand, the choice for the tournament over the piece rate is driven by risk tolerance (H2b).

Finally, focusing on self-selection into the fixed payment, the piece-rate alternative should induce stronger productivity sorting than the tournament: at least some highly productive individuals who choose the piece rate over the fixed payment may prefer the fixed payment over the tournament because they are sufficiently pessimistic about their chance of winning and/or dislike the additional risk that the tournament involves. We therefore expect the pool of workers attracted by the fixed payment to contain fewer highly productive workers when the alternative is the piece rate than when the alternative is the tournament (H3a). Also, we expect that the fixed payment attracts more risk-tolerant workers when the alternative is the piece rate than when the alternative is the tournament (H3b).

Adding a third contract type to a given binary menu An extension of the menu of contracts offers workers more sorting options and hence potentially a better match between the contractual terms and their bundle of productivity and risk attitude. In the full menu PTF, we expect the following sorting pattern to emerge: the piece-rate contract should attract relatively productive and riskaverse workers ( $\mathrm{H} 4 \mathrm{a})$; the tournament contract should attract relatively productive and risk-tolerant workers (H4b); and the fixedwage contract should attract relatively unproductive and risk-averse workers ( $\mathrm{H} 4 \mathrm{c})$. A testable implication of $\mathrm{H} 4 \mathrm{a}$ is that when a fixed payment is added to the menu PT, the piece rate should attract more productive workers than before. Analogously, when a tournament is added to the menu PF, the piece rate should attract less risk-tolerant workers. Hypothesis H4b in turn implies that when a fixed payment is added to the menu PT, the tournament should attract more productive workers than before. Analogously, when a piece rate is added to the menu TF, the tournament should attract more risk-tolerant workers than before. Finally, H4c implies that

\footnotetext{
${ }^{7}$ Note that our definition of self-assessment is specific for the tournament contract and includes all relevant beliefs about others' choices. We do not assume or require these beliefs to be consistent with any game-theoretic notion of equilibrium. In particular, we are agnostic about the degree to which subjects hold common priors and/or perform iterated elimination of weakly or strictly dominated strategies, which from a theoretical perspective is crucial in the equilibrium analysis of tournaments.

${ }^{8}$ This argument holds regardless of the correlation between relative self-assessment and actual productivity. However, for ease of exposition, we assume that beliefs about who enters the tournament do not change, which turns out to be an accurate assumption empirically in our experiment.
} 
when a piece-rate contract is added to the menu TF, the fixed payment should attract less productive and more risk-tolerant workers than before. Analogously, if a tournament is added to the menu PF, the fixed payment should attract less risk-tolerant workers than before. It is not possible to derive a clear prediction on productivity, however.

\subsection{Experimental design and procedures}

The experiment consists of three building blocks: (1) measurement of productivity in a real-effort work task, followed by elicitation of relative self-assessment, preferences and personality traits; (2) sorting decisions into the preferred payment contract in four different environments that differ in terms of the menu of incentive contracts offered; and (3) a work phase in which participants work get rewarded according to their preferred contract. The task is to multiply one-digit numbers by two-digit numbers. ${ }^{9}$

Our experiment proceeds in 12 steps that each refer to a particular aspect of one of the three building blocks. Fig. 1 provides an overview of the experimental set-up. In the first two steps, we elicit productivity. In step 1, we ask subjects to solve one multiplication problem as fast as possible. ${ }^{10}$ No material incentives are offered in this step. Subjects receive feedback on the number of seconds they needed to solve the problem correctly. In step 2, we pay subjects a piece rate of 10 points for each multiplication problem they solve correctly within a time span of five minutes. Each multiplication task is shown on a separate computer screen. A new problem pops up instantaneously on the screen when the problem is solved correctly. In order to prevent subjects from guessing or from avoiding difficult problems, they have to solve a problem correctly before a new one is displayed. Each subject goes through the exact same sequence of problems. A counter on the screen informs subjects about the number of problems they answered correctly. Throughout the paper, we use the number of correctly solved problems in $5 \mathrm{~min}$ as our measure of individual productivity.

After the 5-minute work period, we ask subjects in step 3 to rate on a five-point scale how much effort they exerted, how stressed they felt and how exhausted they got. In step 4, subjects assess how many of the other 23 subjects in their session solved more questions correctly than they did. ${ }^{11}$ This relative self-assessment is incentivized: 100 points are awarded for a correct assessment, 50 points if the answer deviates by one rank from the correct rank, and larger deviations yield zero points. Subjects are informed about the quality of their assessment at the end of the experiment.

Step 5 is the crucial step of our experiment. Subjects choose how they want to be rewarded in the upcoming 10-minute work phase, where they will work on the same type of multiplication problems as in step 2. In contrast to DF, we ask subjects to make choices between payment schemes in four different contractual environments. We refer to these contractual environments as "worlds" in the instructions. We inform subjects that one of these "worlds" will be randomly selected to be the pay-off relevant environment for all participants in the session, and that the remuneration scheme chosen in this "world" determines their rewards for the upcoming 10-minute work phase. In each of the four "worlds", we offer a menu of contracts that consists of different combinations of a piece-rate contract (P), a tournament contract (T) or a fixed-payment contract (F). As explained above, the four different menus of contracts are (i) piece rate vs. fixed payment (PF), (ii) tournament vs. fixed payment (TF), (iii) piece rate vs. tournament (PT) and (iv) piece rate vs. tournament vs. fixed payment (PTF). ${ }^{12}$ Since we observe individual sorting decisions in all four contractual environments, we can study how sorting patterns change when the menu of alternative contracts changes.

In step 6, we elicit beliefs about choices and productivity of the other 23 subjects who participate in the same session. For each of the four contractual environments we first remind subjects of the choice they made in that particular environment, and then ask: "How many of the other 23 participants (excluding yourself) do you think have opted for each of the following payment schemes in this world?" Subjects answer this question for all payment schemes offered in the respective contractual environment. We impose that the numbers they fill in add up to 23 . We also ask them to indicate, for each payment scheme in every contractual environment, how many of the subjects selecting into that scheme they think solved more problems than they themselves did. All questions of this type (4 questions in binary environments, 6 in environment PTF) are incentivized in the same way as the earlier self-assessment question.

In steps 7 to 9 , participants make choices under risk and uncertainty. Step 7 is designed to elicit risk preferences. Following DF, we ask subjects to choose between a lottery and a safe payment in 15 situations, displayed on the 15 rows of a choice table. The lottery in each row offers 50 percent chance of getting 400 points and 50 percent chance of receiving 0 points. The safe payment is 25 points in the first row of the choice table and increases with steps of 25 points to 400 points in row 15 . One row is randomly chosen for payment, and subject are paid according to their choice in that row. The computer randomly determines the outcome of the lottery in case the lottery is chosen. In 270 out of 288 cases, subjects have a unique switching point, defined as the last row in which the subject prefers the lottery to the safe payment, and chooses the safe payment in all remaining rows. We take that switching point as our experimental measure of risk attitude. Individuals who do not have a unique switching point are excluded from analysis where we use this measure.

In step 8, we obtain a measure for attitudes towards losses using the elicitation method developed by Fehr and Goette (2007).

\footnotetext{
${ }^{9}$ As DF point out, this work task requires no previous knowledge, is easy to explain, guarantees a sufficient degree of heterogeneity in productivity, and does not prompt strong learning effects during the experiment.

${ }^{10}$ Step 1 also serves to acquaint subjects with the real effort task, the manner in which the multiplication problem appeared on the computer screen and the way that answers had to be typed into the answer box on the screen.

${ }^{11}$ We inform subjects that the sequence of multiplication problems is identical for all participants.

${ }^{12}$ The order in which the contractual environments appear is randomized over subjects within each session. As it turns out, variable payment schemes are less likely to be chosen on the final screen than on the first three screens. We correct for order effects in the analysis to enhance precision of the estimates.
} 


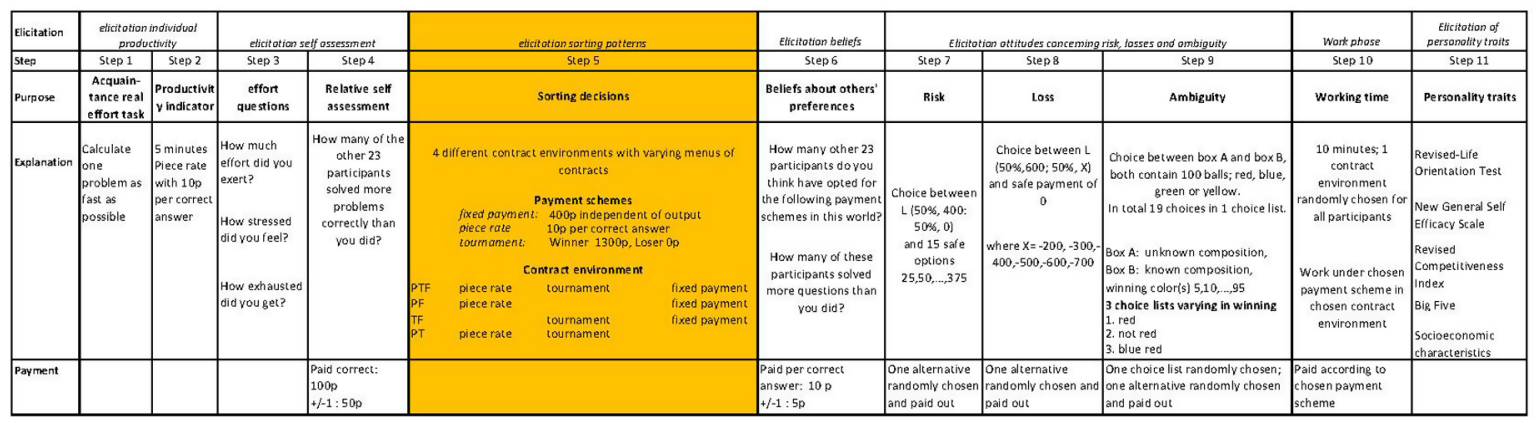

Fig. 1. Overview of experimental design.

Subjects face six different lotteries, in which they can either win or lose money. In each of the six lotteries, individuals have 50 percent chance of winning 600 points, and 50 percent chance of losing an amount. The possible losses vary across the lotteries between 200 and 700 points. For each of the six lotteries, we ask subjects whether they prefer to play the lottery or receive 0 points. This question is incentivized, as one lottery is randomly drawn for payment and played out if the participant prefers the lottery over earning nothing for sure. Again, we define a switching point here, which serves as our experimental measure of loss attitudes (only 4 subjects out of 288 had no well-defined switching point, and are therefore excluded from analysis using this measure). Using the insights from prospect theory (Kahneman \& Tversky, 2013), we conjecture that loss averse individuals find the tournament less attractive because of the possibility that they earn nothing, which they may perceive as a loss relative to a reference point. ${ }^{13}$

We measure attitudes towards uncertainty in step 9. In practice, individuals often make decisions while not knowing the exact probability distribution over all possible outcomes. Those situations are characterized by uncertainty rather than risk. Participation in the tournament is an example of such a decision under uncertainty, as the distribution of productivity of possible opponents, and hence the winning probability, is not precisely known. Uncertainty aversion, also referred to as ambiguity aversion, might therefore negatively affect the attractiveness of participation in the tournament. We measure attitudes towards uncertainty as follows. Subjects are confronted with two boxes called "box A" and "box B". Each box contains 100 balls of 4 possible colors: red, blue, green or yellow. Subjects do not know the color composition of the balls in box A, while the color composition in box B is known. Subjects choose from which of the two boxes they would like to randomly draw a ball. If its color is among the set of pre-specified "winning colors" the subject receives a prize. We administer three sets of winning colors (red, not-red, red-and-blue). The procedure is then similar to choice list method we exploit to measure risk and loss aversion. Subjects fill out three choice lists, one list of choices for each set of winning colors. The composition of box A is always the same (but unknown). For a given choice list, we vary the number of winning balls in box B - i.e. the known winning probability - between 5 and 95. Subjects indicate their preference in all situations listed, in all three choice lists. Thereafter, the computer randomly selects one choice list and one row in that list, which determines the subject's earnings according to her choice. ${ }^{14}$ We then combined the switching points in all situations to an experimental measure of ambiguity attitude. $^{15}$

Step 10 of the experiment is the work-phase. As explained above, one of the four contractual environments is selected at random. Subjects are informed about the "world" the computer selected, and reminded about the payment scheme they have chosen in that environment in step 5 . Individuals then work for $10 \mathrm{~min}$.

Immediately after the 10-minute work period, we ask participants in step 11 how exhausted they are, how stressed they feel, and how much effort they exerted (same questions as in step 3). We then inform subjects about their earnings in the experiment. Finally, in step 12, we measure subjects' personality traits using various psychological scales. Specifically, we use the Revised Life Orientation Test (Scheier, Carver, \& Bridges, 1994) to measure optimism, and we use the New General Self Efficacy Scale (Chen, Gully, \& Eden, 2001) to measure self-efficacy. ${ }^{16}$ We measure competitiveness using the Revised Competitiveness Index (Houston, Harris, McIntire, \& Francis, 2002), which is presumably related to sorting into tournaments. We also measure the Big Five personality traits using a scale developed by Gerlitz and Schupp (2005). Furthermore, we ask subjects the "general risk question" which is validated by Dohmen et al. (2011). To facilitate comparison with DF, we use self-reported willingness to take risk as the default measure for risk attitude. Finally, we gather information on subjects' socioeconomic characteristics such as gender, age, nationality, study program, and years of study.

\footnotetext{
${ }^{13}$ In environment TF, the fixed payment of 400 is a salient reference point. In environment PF, a salient reference point is what the individual expects to earn when choosing the piece rate scheme. In environment PTF, it could be the highest of the two values depending on the individual's expected productivity.

${ }^{14}$ We vary the number of winning colors of the balls in order to measure likelihood insensitivity (see Abdellaoui, Baillon, Placido, \& Wakker, 2011), the extent to which individuals are sensitive to changes in their chances of winning in ambiguous situations.

${ }^{15}$ See Abdellaoui et al., 2011 for details on the construction of this measure. Note that 229 out of 288 subjects had unique switching points in all three scenarios. We exclude individuals who do not have a unique switching point from analyses based on this measure.

${ }^{16}$ Self-efficacy is defined as an individual's belief in her ability to reach a goal (e.g., complete a task).
} 


\subsubsection{Experimental procedures}

All experimental sessions were conducted at the laboratory run by the Economics faculty of a European university. ${ }^{17}$ All subjects were students of this university, about $70 \%$ of them studying economics or business administration. Other prominent fields of study were law and cultural sciences. Subjects were recruited using Orsee (Greiner, 2004). Each subject participated in only one session. The experiments were programmed using the software z-Tree (Fischbacher, 2007). Once all subjects were seated, they received a written overview stating that the experiment would consist of different parts. No helping devices (such as paper and pencil, pocket calculators, or cell phones) were allowed, nor was any form of communication. In total, we conducted 12 sessions with exactly 24 participants per session, so that $\mathrm{N}=288$. During the experiment, subjects earned points, which were converted to cash at the end of the experiment, the exchange rate being 10 points $=€ 0.13$. Subjects were paid in private immediately at the end of the experiment. Mean earnings were about $€ 17$ with session length averaging $75 \mathrm{~min}$.

\section{Results}

\subsection{Descriptive statistics}

We first present some descriptive statistics. Table 1 shows correlations between various measures. The first thing to note is that individuals have on average quite accurate relative self-assessment. The pairwise correlation with actual productivity is 0.64 . Our measure of risk attitude, i.e. the stated willingness to take risks, has a correlation of 0.25 with the experimental measure of risk attitude, and 0.22 with the experimental measure of loss attitude.

Although we focus on self-selection based on productivity, relative self-assessment, and risk attitude, we also collected a number of personality traits and attitudes that we expect to correlate with those characteristics. For instance, the competitiveness scale is highly positively correlated with stated willingness to take risks as well as with relative self-assessment. Optimism and self-efficacy are also positively related to relative self-assessment. Finally, women in our experiment are less risk tolerant and less competitive than men. Consistent with DF, they are also slightly less productive in this particular task. Table A4 in the appendix provides further details on gender differences in personality traits and attitudes, and shows that gender differences in productivity, risk attitude and competitiveness are statistically significant. ${ }^{18}$

\subsection{Sorting patterns in environments with two contract alternatives}

We start our analysis by analyzing the sorting patterns in environments where workers choose between two contracts. We expect that productivity, risk attitude and relative self-assessment are important sorting dimensions when workers choose between a fixed wage and a variable payment scheme. Another potentially important sorting dimension is gender, since there is a substantial literature showing that women tend to shy away from tournaments (e.g. Niederle \& Vesterlund, 2007). Understanding sorting on gender is important for organizations, because they may benefit from gender diversity. The descriptive statistics reported in Table 2 provide a first indication of sorting patterns.

The table shows for each binary menu of contracts the key characteristics of workers who sort into a particular payment scheme. Clearly, variable payment schemes attract more productive workers when the alternative is a fixed payment. Also consistent with prior expectations, the tournament attracts relatively more risk-tolerant workers. As individuals' relative self-assessments are highly correlated with their actual productivity $(r=0.64)$, variable payment schemes, which attract productive workers, also attract workers with high relative self-assessment. When pitted against each other, the variable payment schemes attract workers of similar productivity, but workers who choose the tournament have significantly more optimistic beliefs about their relative productivity. Finally, women are - unconditionally - less willing to work under variable payment schemes.

We obtain more insight into sorting patterns by estimating probit models. For each menu of contracts, we estimate a simple model that includes individuals' productivity, relative self-assessment, risk attitude, gender, and order effects. We also estimate a probit model with additional controls, specifically survey measures of self-efficacy, optimism, competitiveness, and Big-5 personality traits. The results, reported in Table 3, are again consistent with our conjectures: productive workers sort into variable payment schemes. ${ }^{19}$

Investigating the distinction between productivity and relative self-assessment in more detail, we find that productive workers prefer the piece rate over the fixed payment regardless of their relative self-assessment. At the same time, keeping productivity constant, workers with higher relative self-assessment prefer the tournament over fixed pay as well as the piece rate. The estimated mean marginal effects and pseudo R-squared hardly change when we add further control variables, suggesting that productivity, relative self-assessment, and risk attitude are key determinants of the sorting decision.

Gender differences that show up unconditionally in the raw data disappear when we control for productivity and risk attitudes. The characteristics that drive gender differences in compensation choice depend on the contractual environment. For instance, in environment $\mathrm{PF}$, individuals sort on productivity while risk attitudes are unimportant. In such an environment, gender differences

\footnotetext{
17 The experiment received formal approval from the institution where it took place.

${ }^{18}$ Additional analysis shows that correcting for productivity differences, there are no statistically significant gender differences in relative selfassessment.

${ }^{19}$ Competitive individuals are more likely to choose the tournament than the piece rate. However, this is ultimately driven by risk preferences: attitudes towards competition become insignificant when correcting for risk attitudes.
} 
Table 1

Pearson correlation matrix between the behavioral measures.

\begin{tabular}{|c|c|c|c|c|c|c|c|c|c|}
\hline & Productivity & $\begin{array}{l}\text { Risk } \\
\text { attitude }\end{array}$ & $\begin{array}{l}\text { Self- } \\
\text { assessment }\end{array}$ & Female & $\begin{array}{l}\text { Risk attitude } \\
\text { (lottery) }\end{array}$ & $\begin{array}{l}\text { Loss } \\
\text { attitude }\end{array}$ & $\begin{array}{l}\text { Ambiguity } \\
\text { attitude }\end{array}$ & Competitiveness & Optimism \\
\hline Productivity & 1 & & & & & & & & \\
\hline Risk attitude & -0.05 & 1 & & & & & & & \\
\hline Self-assessment & 0.64 & 0.08 & 1 & & & & & & \\
\hline Female & -0.14 & -0.15 & -0.13 & 1 & & & & & \\
\hline $\begin{array}{r}\text { Risk attitude } \\
\text { (lottery) }\end{array}$ & -0.05 & 0.25 & 0.02 & -0.21 & 1 & & & & \\
\hline Loss attitude & -0.12 & 0.22 & -0.04 & -0.09 & 0.28 & 1 & & & \\
\hline Ambiguity attitude & 0.04 & -0.04 & 0.09 & -0.12 & 0.21 & 0.14 & 1 & & \\
\hline Competitiveness & 0.24 & 0.36 & 0.22 & -0.25 & 0.13 & 0.01 & 0.02 & 1 & \\
\hline Optimism & 0.11 & 0.14 & 0.26 & -0.03 & 0.09 & 0.00 & -0.00 & 0.29 & 1 \\
\hline Self Efficacy & 0.18 & 0.17 & 0.27 & -0.15 & 0.14 & 0.01 & -0.01 & 0.34 & 0.47 \\
\hline
\end{tabular}

Note: pairwise correlations between variables. Productivity is the number of multiplication problems solved in the 5-minutes work stage before participants make their sorting decision. Risk attitude is the subjectively measured willingness to take risks, where higher values indicate higher willingness to take risks. Relative self-assessment is an individual's belief about the number of participants he or she outperforms, so that higher values indicate a positive belief about own relative productivity. Risk attitude (lottery) is the number of lotteries preferred over a fixed payment when individuals make a number of choices between a lottery and a fixed payment. Loss attitude likewise measures the number of lotteries preferred over receiving nothing, where the lotteries give a chance on gaining or losing money. Ambiguity attitude measures the willingness to gamble in uncertain situations. Competitiveness is measured as individuals' stated willingness to compete. Optimism is measured using the Revised Life Orientation test. Self-efficacy is measured by use of the New General Self-Efficacy Scale.

Table 2

Descriptive statistics in environments with two contract alternatives.

\begin{tabular}{|c|c|c|c|c|c|}
\hline & $\mathrm{N}$ & Productivity & Risk attitude & Relative self assessment & Proportion women \\
\hline \multicolumn{6}{|l|}{ PF } \\
\hline Piece rate & 153 & $\begin{array}{l}26.69 \\
(9.15)\end{array}$ & $\begin{array}{l}6.26 \\
(1.81)\end{array}$ & $\begin{array}{l}16.07 \\
(4.68)\end{array}$ & $\begin{array}{l}0.44 \\
(0.50)\end{array}$ \\
\hline Fixed Payment & 135 & $\begin{array}{l}17.23 \\
(8.32)\end{array}$ & $\begin{array}{l}6.24 \\
(1.94)\end{array}$ & $\begin{array}{l}12.13 \\
(5.00)\end{array}$ & $\begin{array}{l}0.58 \\
(0.50)\end{array}$ \\
\hline \multicolumn{6}{|l|}{$\mathrm{TF}$} \\
\hline Tournament & 155 & $\begin{array}{l}26.10 \\
(9.51)\end{array}$ & $\begin{array}{l}6.52 \\
(1.87)\end{array}$ & $\begin{array}{l}16.39 \\
(4.48)\end{array}$ & $\begin{array}{l}0.45 \\
(0.50)\end{array}$ \\
\hline Fixed Payment & 133 & $\begin{array}{l}17.77 \\
(8.51)\end{array}$ & $\begin{array}{l}5.94 \\
(1.82)\end{array}$ & $\begin{array}{l}11.7 \\
(4.87)\end{array}$ & $\begin{array}{l}0.56 \\
(0.50)\end{array}$ \\
\hline \multicolumn{6}{|l|}{ PT } \\
\hline Piece rate & 181 & $\begin{array}{l}21.92 \\
(9.46)\end{array}$ & $\begin{array}{l}5.81 \\
(1.87)\end{array}$ & $\begin{array}{l}13.35 \\
(5.07)\end{array}$ & $\begin{array}{l}0.56 \\
(0.50)\end{array}$ \\
\hline Tournament & 107 & $\begin{array}{l}22.82 \\
(10.77)\end{array}$ & $\begin{array}{l}7.00 \\
(1.60)\end{array}$ & $\begin{array}{l}15.7 \\
(5.14)\end{array}$ & $\begin{array}{l}0.41 \\
(0.49)\end{array}$ \\
\hline
\end{tabular}

We report means, with standard deviations in parentheses. Productivity is the number of multiplication problems solved in the 5-minutes work stage before participants make their sorting decision. Risk attitude is the subjectively measured willingness to take risks, where higher values indicate higher willingness to take risks. Relative self-assessment is an individual's belief about the number of participants he or she outperforms, so that higher values indicate a positive belief about own relative productivity.

simply reflect productivity differences: the gender coefficient is no longer statistically significant after controlling for productivity. By contrast, in environment PT risk attitudes are highly important, implying that gender differences are driven by differences in risk attitude.

The results are the same when we use behavior in incentivized lotteries as measure of risk attitudes, even after correcting for attitudes towards losses and ambiguity. Results are reported in Table A2. While attitudes towards losses and ambiguity explain sorting behavior in environment TF in the expected direction, they are not significantly related to choices in environment PT after correcting for risk attitude. This again shows that risk attitude is a key determinant of sorting decisions. ${ }^{20}$

An interesting question is to what extent survey measures of optimism, self-efficacy and competitiveness predict sorting patterns. Table A4 shows the estimation results of two specifications: a probit model where we explain choices by productivity and aforementioned variables, and the same model where we additionally control for risk attitude and relative self-assessment. Wald

\footnotetext{
${ }^{20}$ Note that this analysis excludes individuals who do not have a unique switching point in our measures of risk, loss or ambiguity attitude. We obtain similar results when we include them in the analysis assuming that their switching point equals the average switching point. Results of our main analysis in Table 3 also do not change when we restrict the sample to individuals who make consistent choices in all three measures.
} 
Table 3

Sorting patterns in different contractual environments.

\begin{tabular}{|c|c|c|c|c|c|c|}
\hline \multirow[t]{2}{*}{$\begin{array}{l}\text { Contractual environment } \\
\text { Dependent variable }\end{array}$} & \multicolumn{2}{|c|}{$\begin{array}{l}\text { Menu PF } \\
1=\text { piece rate }\end{array}$} & \multicolumn{2}{|c|}{$\begin{array}{l}\text { Menu TF } \\
1=\text { tournament }\end{array}$} & \multicolumn{2}{|c|}{$\begin{array}{l}\text { Menu PT } \\
1=\text { piece rate }\end{array}$} \\
\hline & (1) & (2) & (3) & (4) & (5) & (6) \\
\hline Productivity & $\begin{array}{l}0.019^{\text {thete }} \\
(0.002)\end{array}$ & $\begin{array}{l}0.019^{\text {thx }} \\
(0.003)\end{array}$ & $\begin{array}{l}0.012^{\text {thes }} \\
(0.003)\end{array}$ & $\begin{array}{l}0.013^{\text {veltet }} \\
(0.003)\end{array}$ & $\begin{array}{l}0.005^{*} \\
(0.003)\end{array}$ & $\begin{array}{l}0.005^{\text {**k }} \\
(0.002)\end{array}$ \\
\hline Risk attitude & $\begin{array}{l}0.003 \\
(0.014)\end{array}$ & $\begin{array}{l}-0.007 \\
(0.014)\end{array}$ & $\begin{array}{l}0.033^{* *} \\
(0.014)\end{array}$ & $\begin{array}{l}0.036^{k+k} \\
(0.016)\end{array}$ & $\begin{array}{l}-0.069^{\text {*tate }} \\
(0.011)\end{array}$ & $\begin{array}{l}-0.059 \\
(0.013)\end{array}$ \\
\hline Relative self-assessment & $\begin{array}{l}0.011 \\
(0.006)\end{array}$ & $\begin{array}{l}0.007 \\
(0.005)\end{array}$ & $\begin{array}{l}0.027^{2} \\
(0.004)\end{array}$ & $\begin{array}{l}0.023^{\text {tekik }} \\
(0.006)\end{array}$ & $\begin{array}{l}-0.022^{\text {***k }} \\
(0.005)\end{array}$ & $\begin{array}{l}-0.021 \\
(0.005)\end{array}$ \\
\hline Female & $\begin{array}{l}-0.080 \\
(0.057)\end{array}$ & $\begin{array}{l}-0.040 \\
(0.060)\end{array}$ & $\begin{array}{l}-0.033 \\
(0.034)\end{array}$ & $\begin{array}{l}-0.052 \\
(0.038)\end{array}$ & $\begin{array}{l}0.057 \\
(0.052)\end{array}$ & $\begin{array}{l}0.052 \\
(0.057)\end{array}$ \\
\hline Order effects & yes & yes & yes & yes & yes & yes \\
\hline Additional controls & no & yes & no & yes & no & yes \\
\hline Observations & 288 & 288 & 288 & 288 & 288 & 288 \\
\hline Pseudo R-squared & 0.21 & 0.24 & 0.23 & 0.25 & 0.14 & 0.17 \\
\hline
\end{tabular}

Probit estimates, average marginal effects. Standard errors (in parentheses) are clustered on session level. ${ }^{* * *},{ }^{* *}$ and * denote statistical significance at the $1 \%, 5 \%$ and $10 \%$ level, respectively. Productivity is the number of multiplication problems solved in the 5-minutes work stage before participants make their sorting decision. Risk attitude is the subjectively measured willingness to take risks, where higher values indicate higher willingness to take risks. Relative self-assessment is an individual's belief about the number of participants he or she outperforms, so that higher values indicate a positive belief about own relative productivity. Additional controls include survey measures of optimism, self-efficacy, competitiveness, and Big-5 personality traits.

$* * *$ Denotes statistical significance at the $1 \%$ level.

** Denotes statistical significance at the $5 \%$ level.

* Denotes statistical significance at the $10 \%$ level.

tests show that optimism, self-efficacy and competitiveness are jointly statistically significant in environments PT and TF, but not in PF. They are statistically significant at the five percent level when we do not control for risk attitude and relative self-assessment, and at the ten percent level when we add those controls. Self-efficacy in particular is positively associated with choosing the tournament, while this association is less clear for competitiveness and optimism. Those results suggest that the sorting patterns we report in Table 3 are related to various validated measures of personality, which speaks in favor of the external validity of our findings.

As our experimental design is based on DF, it is instructive to compare their results to ours. We find similar patterns: variable payment schemes tend to attract the more productive workers, and tournaments attract workers with higher relative self-assessment and risk tolerance. As the parametrization is identical, we can directly compare coefficient estimates from identical regressions, reported in Table A1. The sorting patterns in both data sets are virtually identical. The only difference is that DF find a highly significant relation between risk attitudes and sorting into piece rates, whereas we do not. ${ }^{21}$ Hence, we replicate the results of DF, and in addition show that relative self-assessment is a key sorting dimension when individuals are offered the choice between the piece rate and the tournament.

\subsection{Comparison of sorting patterns across environments with two contract alternatives}

Hypotheses $\mathrm{H} 1 \mathrm{a} / \mathrm{b}, \mathrm{H} 2 \mathrm{a} / \mathrm{b}$ and $\mathrm{H} 3 \mathrm{a} / \mathrm{b}$ discuss how the composition of the workforce attracted by a particular contract is affected when the alternative contract changes. We will now present the sorting patterns in the data using Figs. 2-4. Fig. 2 shows the characteristics of workers who opt for the piece rate when the alternative is the tournament (upper box: environment PT) compared to those who choose the piece rate when then the alternative is the fixed payment (lower box: environment PF). Consistent with H2a, average productivity of piece-rate workers is lower in PT (21.92 correct answers in 5 min) than in PF (26.69 correct answers in $5 \mathrm{~min}$ ). This difference is statistically significant at the one-percent level. ${ }^{22}$ Fig. 2 also shows the characteristics of workers who choose the piece rates in both environments, and of those who switch when the contractual environment changes. This allows us to assess what drives the changes in average productivity of piece-rate workers when the environment changes. Largely, the difference is driven by the 78 relatively low-productive workers (average productivity: 16.36) who opt for the fixed payment in PF, but prefer the

\footnotetext{
${ }^{21}$ A possible reason is that the subject pool in DF has less confidence in their ability to perform consistently. We find a positive coefficient (0.044) when we concentrate on marginal types (productivity 18-22), but the coefficient is not statistically significant $(p<0.21)$, presumably because of the smaller sample size $(\mathrm{N}=61)$.

${ }^{22}$ See Table 4 for significance levels. Since workers who choose a particular contract in both environments are partially the same individuals, standard paired or unpaired t-tests do not apply. We therefore derive p-values from cluster-robust regressions. Specifically, we duplicate observations and create a dummy which takes value 0 if an individual chooses e.g. the piece rate in PF, and 1 if the duplicated individual chooses the piece rate in PT. We then regress productivity on this indicator, with standard errors clustered on the individual.
} 


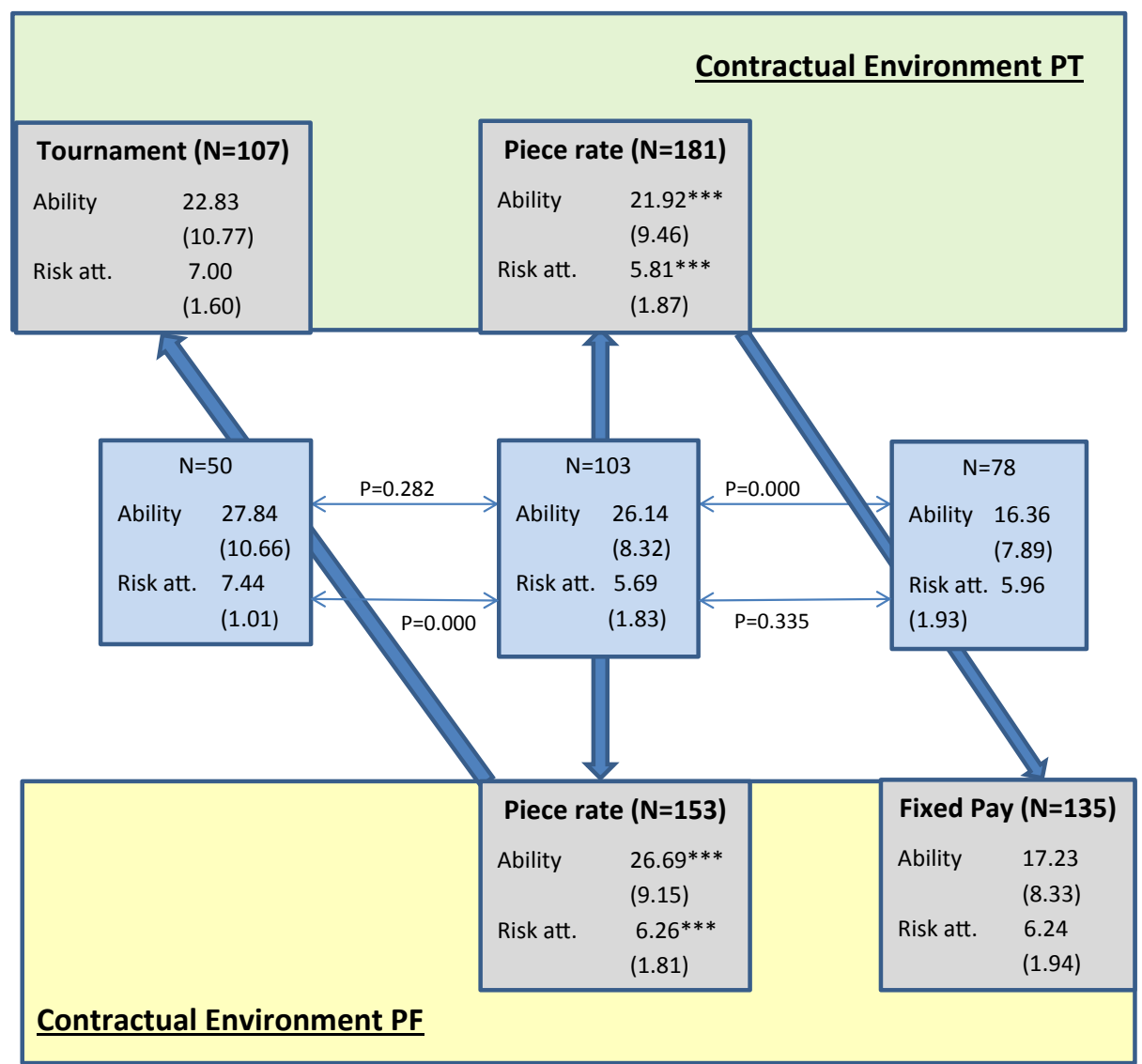

Fig. 2. Flow diagram showing average characteristics of workers who choose the piece rate in environments PT and/or PF.

piece rate in PT. At the same time, workers who prefer the tournament in PT, but switch to the piece rate in PF are of similar productivity as those who choose the piece rate in both environments. However, the former are significantly more willing to take risks: the tournament attracts more risk-tolerant workers. This illustrates why, consistent with $\mathrm{H} 2 \mathrm{~b}$, the piece rate attracts less risk tolerant individuals when the alternative is a tournament than when the alternative is a fixed payment (5.81 vs. 6.26 ; $t$-test, $\mathrm{p}$ value $<0.001$ ).

Fig. 3 illustrates the characteristics of workers who choose the tournament in contractual environments PT (upper box) and TF (lower box). The tournament attracts significantly more productive $(\mathrm{p}<0.001)$ individuals when the alternative is a fixed payment than when the alternative is a piece rate. This difference is driven by a small number $(\mathrm{N}=33)$ of very unproductive workers who prefer the tournament over the piece rate, but switch to the fixed payment in environment TF. While such low productivity workers should only choose the tournament when they have very optimistic beliefs, it makes sense for them to switch to the fixed payment since the fixed payment gives them a higher payoff than the piece rate. ${ }^{23}$ Fig. 3 also illustrates that tournament workers in environment PT are on average more willing to take risks than tournament workers in $\mathrm{TF}$ ( $\mathrm{p}<0.004)$. This is consistent with the idea that there is strong sorting on risk attitudes when the alternative is a piece rate, since productive workers who do not like to take risks have an attractive alternative. The data provide direct evidence for this mechanism: workers who choose the tournament in environment TF and switch to the piece rate in environment PT, are just as productive as workers who choose the tournament in both environments, but significantly less willing to take risks. Hence, the tournament in PT tends to attract relatively less productive and more risk seeking individuals than the same tournament offered in TF, which is consistent with H3a and H3b.

Fig. 4 illustrates the characteristics of workers who choose the fixed payment in environments TF and PF. Workers who choose the fixed payment are of similar productivity in both environments. This is not because these are the exact same individuals: there are quite some workers who switch when the contractual environment changes. Rather, it is because those who switch to and from the

\footnotetext{
${ }^{23}$ Workers who opt for the tournament in PT but switch to the fixed payment in TF are far more optimistic than those who choose the piece rate in PT and the fixed payment in TF (subjective winning chance in PT: 0.36 vs 0.24 ). Those differences in beliefs rationalize differences in behavior, because the tournament gives a higher expected payoff than the piece rate with a subjective winning probability of 0.36 , but not with a subjective winning probability of 0.24 (assuming subject expect to solve $2 * 16=32$ multiplications in $10 \mathrm{~min}$ ).
} 


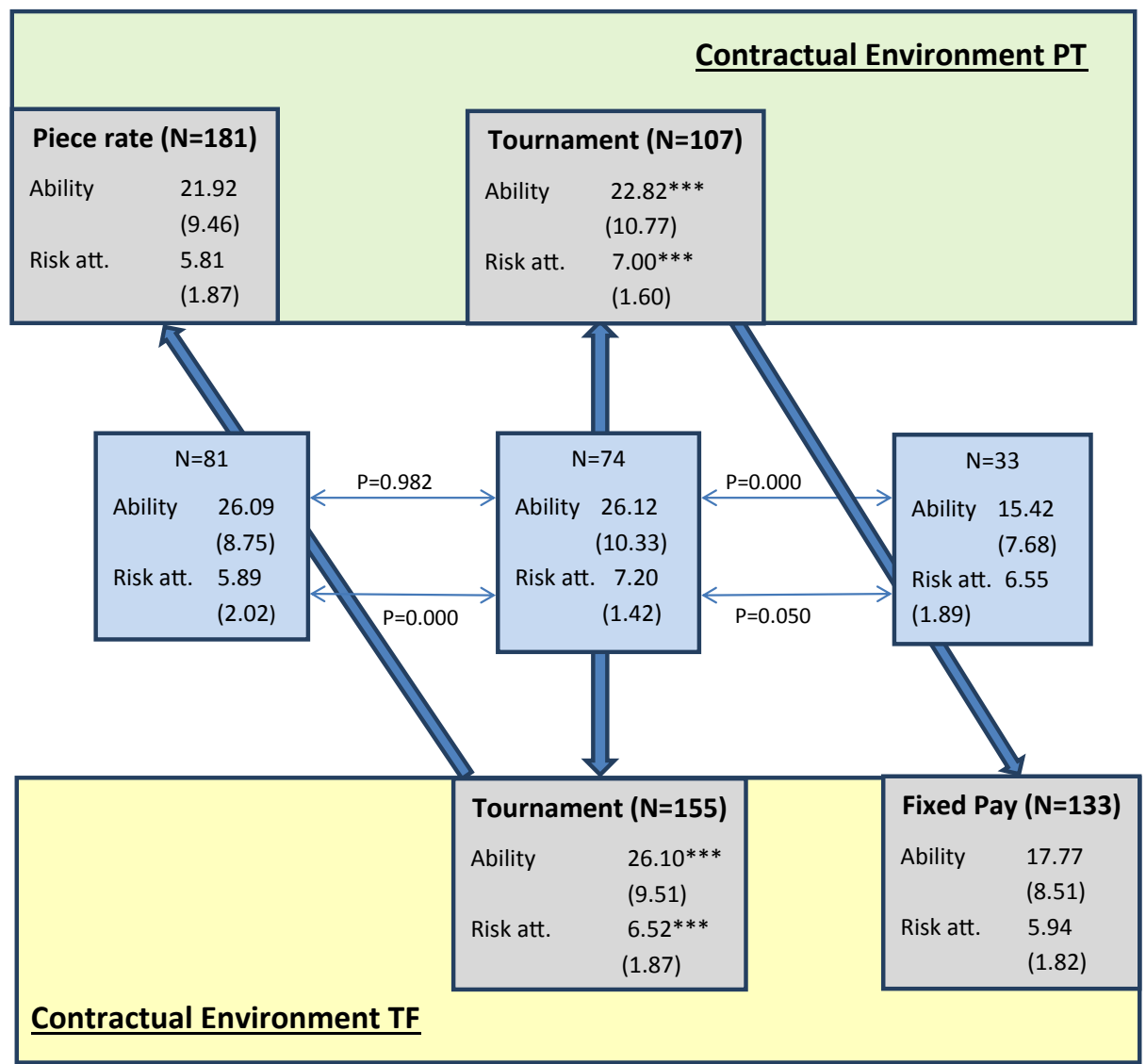

Fig. 3. Flow diagram showing average characteristics of workers who choose the tournament in environments PT and/or TF.

fixed payment are, on average, similarly productive. This masks, however, that the fixed payment attracts more workers with a productivity over 20 when the alternative is the tournament than when the alternative is the piece rate: 30 percent in the former case compared to 24 percent in the latter case. This is further illustrated by Fig. B5 in the appendix: the right tail of fixed wage choosers' productivity distribution is thicker when the alternative is the tournament. This is driven by some productive workers who shy away from the tournament, consistent with H3a. Those workers are also less risk tolerant, implying that the fixed payment attracts less risk tolerant individuals when the alternative is the tournament than when the alternative is the piece rate (H1b). This is illustrated by Fig. 4: workers who switch to the tournament are significantly more willing to take risks than workers who choose the fixed payment in both contractual environments.

\subsection{Extending the menu of contracts}

In the previous section we analyzed how a particular contract attracts different workers when the alternative contract changes. In this section, we show what happens when a contract is added to the menu of available contracts. Hypotheses $4 \mathrm{a} / \mathrm{b} / \mathrm{c}$ suggest that an extension of the menu of contracts triggers more refined sorting patterns: workers with distinct bundles of productivity and willingness to take risks are attracted to each of the contract alternatives. Table 4 compares average productivity and willingness to take risks of workers attracted by a particular contract in different environments. Panel A compares characteristics of piece rate choosers between contractual environments PF, PT and PTF; while panels B and C analogously compare characteristics of tournament and fixed wage choosers, respectively. Comparisons across rows show how sorting patterns change when the contractual environment is altered. Columns 1-3 display the absolute levels and standard errors, while columns 4-6 show the comparisons and statistical significance of differences. We discussed differences between binary contracts (column 4) in the previous section; here we concentrate on the last two columns.

Starting with workers who choose the piece rate (Panel A), two changes stand out when the menu of contracts is extended. Productivity of workers attracted by the piece rate dramatically increases when a fixed payment is added to the menu PT. This is 


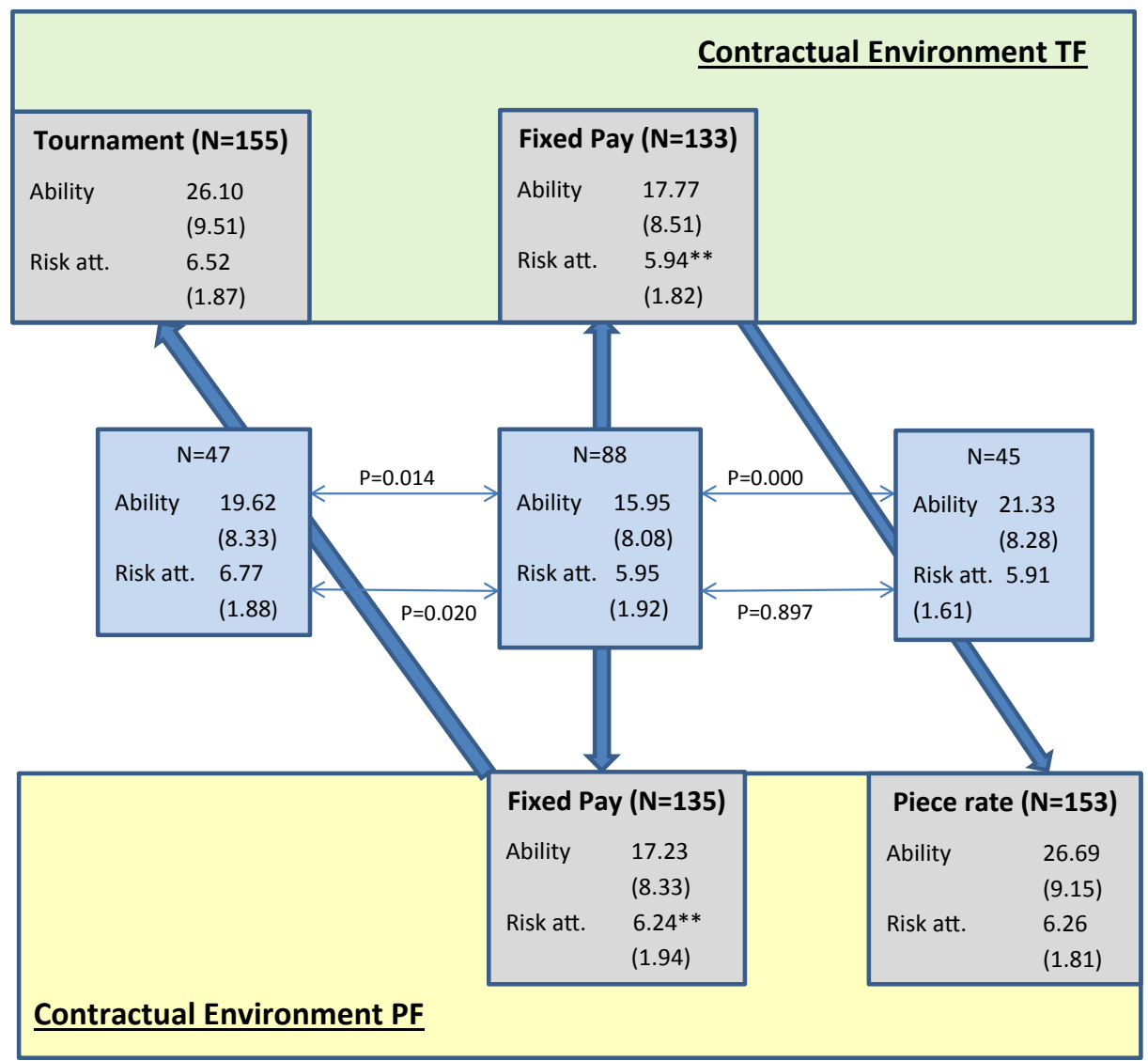

Fig. 4. Flow diagram showing average characteristics of workers who choose the fixed wage in environments TF and/or PF.

exactly what we would expect (H4a), as unproductive workers resort to the fixed payment. Adding a tournament to the menu PF only slightly decreases productivity of piece-rate workers, but it has a strong effect on risk attitudes (again in line with H4a). Since the tournament attracts workers with a high willingness to take risks, the piece rate now attracts less risk-tolerant workers. This shows once more that risk attitudes are a vital determinant of the choice between the tournament and the piece rate.

Turning to Panel B, we see that average productivity among tournament participants decreases when a piece rate is added to menu TF, and increases when a fixed payment is added to menu PT. These effects are rather small, however, and significant only at the 10 percent level. Apparently, the fixed payment is only a weak substitute for the tournament: unproductive workers predominantly prefer the piece rate over the tournament in environment PT. An extension of the menu with the fixed payment therefore more heavily affects the average productivity of workers who opt for the piece rate. ${ }^{24}$ Hypothesis H4b posits that workers who are attracted by the tournament tend to be particularly risk seeking when they also have the option to choose the fixed payment and the piece rate. The data confirm this expectation. Adding a piece rate to the menu TF has a strikingly positive effect on the risk tolerance of workers who choose the tournament. This again reflects that productive workers base their choice between piece rate and tournament on risk attitudes. Adding a fixed payment to menu TP does not significantly affect the risk attitude of tournament-choosers. Although workers who switch to the fixed payment in PTF are relatively unproductive, they are not necessarily less risk seeking than workers choose the tournament in both environments.

Finally, Panel C shows the characteristics of workers who choose the fixed payment in different environments. Consistent with hypothesis $\mathrm{H} 4 \mathrm{c}$, adding a piece rate to the menu TF reduces average productivity of workers on a fixed pay contract. Adding a tournament to the menu PF has a similar effect on productivity, but smaller and no longer statistically significant. The effect on risk attitudes is in the expected direction (lower risk tolerance), but too small to reach statistical significance ( $p<0.106$ ). Note, however, that only 34 workers switch from the fixed payment in PF to the tournament in PTF, which makes it hard to detect statistically significant differences.

All in all, the overall pattern corroborates our hypotheses: an extension of the menu of contract leads to more refined sorting

\footnotetext{
${ }^{24}$ To be specific: of the 97 workers who choose the fixed payment in TPF, only 36 workers choose the tournament in TP while 61 workers choose the piece rate.
} 
Table 4

Productivity and risk attitude by contract choice and contractual environment.

\begin{tabular}{|c|c|c|c|c|c|}
\hline \multicolumn{6}{|c|}{ Panel A: piece rate choosers } \\
\hline & & & Productivity: & & \\
\hline PF & PT & PTF & $\triangle \mathrm{PF}-\mathrm{PT}$ & $\triangle$ PF-PTF & $\Delta$ PT-PTF \\
\hline 26.693 & 21.923 & 25.750 & 4.77 & 0.943 & -3.827 \\
\hline (9.153) & (9.457) & (8.613) & $p<0.001$ & $p<0.060$ & $p<0.001$ \\
\hline \multirow[t]{2}{*}[\mathrm{N}=153]{} & {$[\mathrm{N}=181]$} & {$[\mathrm{N}=120]$} & & & \\
\hline & & & Risk attitude: & & \\
\hline PF & PT & PTF & $\Delta$ PF-PT & $\Delta$ PF-PTF & $\triangle$ PT-PTF \\
\hline 6.261 & 5.807 & 5.900 & 0.455 & 0.361 & -0.093 \\
\hline$(1.806)$ & $(1.874)$ & $(1.804)$ & $p<0.001$ & $p<0.001$ & $p<0.453$ \\
\hline$[\mathrm{N}=153]$ & {$[\mathrm{N}=181]$} & {$[\mathrm{N}=120]$} & & & \\
\hline \multicolumn{6}{|c|}{ Panel B: tournament choosers } \\
\hline & & & Productivity: & & \\
\hline TF & PT & PTF & $\Delta$ TF-PT & $\Delta$ TF-PTF & $\triangle$ PT-PTF \\
\hline 26.103 & 22.822 & 24.451 & 3.281 & 1.652 & -1.628 \\
\hline (9.507) & $(10.768)$ & $(9.834)$ & $p<0.001$ & $p<0.094$ & $p<0.093$ \\
\hline \multirow[t]{2}{*}[\mathrm{N}=155]{} & {$[\mathrm{N}=107]$} & {$[\mathrm{N}=71]$} & & & \\
\hline & & & Risk attitude: & & \\
\hline TF & PT & PTF & $\Delta$ TF-PT & $\Delta$ TF-PTF & $\Delta \mathrm{PT}-\mathrm{PTF}$ \\
\hline 6.516 & 7.000 & 7.127 & -0.484 & -0.611 & -0.127 \\
\hline (1.874) & (1.602) & (1.684) & $p<0.004$ & $p<0.002$ & $p<0.479$ \\
\hline$[N=155]$ & {$[\mathrm{N}=107]$} & {$[\mathrm{N}=71]$} & & & \\
\hline \multicolumn{6}{|c|}{ Panel C: fixed wage choosers } \\
\hline & & & Productivity: & & \\
\hline PF & TF & PTF & $\Delta$ PF-TF & $\triangle$ PF-PTF & $\Delta$ TF-PTF \\
\hline 17.230 & 17.774 & 16.33 & -0.545 & 0.9 & 1.445 \\
\hline (8.325) & $(8.511)$ & (8.917) & $p<0.389$ & $p<0.135$ & $p<0.044$ \\
\hline \multirow[t]{2}{*}[\mathrm{N}=135]{} & {$[\mathrm{N}=133]$} & {$[\mathrm{N}=97]$} & & & \\
\hline & & & Risk attitude: & & \\
\hline PF & TF & PTF & $\Delta$ PF-TF & $\Delta$ PF-PTF & $\Delta$ TF-PTF \\
\hline 6.237 & 5.940 & 6.041 & 0.297 & 0.196 & -0.101 \\
\hline (1.940) & $(1.816)$ & (1.871) & $p<0.022$ & $p<0.106$ & $p<0.458$ \\
\hline$[\mathrm{N}=135]$ & {$[N=133]$} & {$[\mathrm{N}=97]$} & & & \\
\hline
\end{tabular}

Standard errors in parentheses. $p$-values are derived from cluster-robust regressions, see footnote 19.

patterns. Productive workers sort into variable payment schemes, and risk attitudes are decisive for the choice between the tournament and the piece rate.

\section{Concluding remarks}

An organization's success does not depend on worker productivity alone. Workers' preferences, attitudes and personality determine an organization's culture, govern decision-making processes, and affect relationships with customers and clients. Attracting workers with the "right" bundle of skills, preferences, attitudes and personality is therefore crucial for organizational performance. Since an organization's incentive structure fundamentally affects its workers' utility, it is easy to see that the incentive scheme determines which types of workers feel attracted to the organization. However, when designing their own contract, organizations have to take the alternative contracts individuals can choose from into account, as these affect individuals' relative utility and hence their sorting decision. Our experimental results highlight this point: The type of individuals attracted by a particular incentive scheme does not only depend on the inherent characteristics of the scheme, but also on the alternative schemes they can choose from. Our data illustrate that the very same contract attracts workers with different productivity and risk attitude when the alternative contract changes, or when an alternative is added to the menu of available contracts.

While this insight might seem trivial, the basic idea that sorting patterns can be changed by altering the menu of alternative contracts is a powerful one. A first implication is that organizations have to be sensitive to the environment they are operating in. To illustrate, consider a stylized piece-rate firm that is operating in environment PTF, and suppose that competitors who offer fixedpayment contracts either go out of business or switch to variable incentive schemes. This reduces the average productivity of those applying to the firm offering a piece-rate contract. A second implication is that menus of contracts can be designed to sort workers to tasks for which their bundle of characteristics is most suitable. For example, an organization with multiple divisions could offer a menu of contracts to sort trainees into jobs and divisions where their characteristics are most profitable. Divisions where small 
mistakes have severe negative consequences on output could offer a piece rate contract to attract highly productive and risk-averse workers, while divisions where mistakes are less harmful and where risk-taking fosters innovation could offer a tournament to attract productive and risk-tolerant workers. Divisions where individual productivity is less important, e.g. because work is organized in teams or because productivity largely depends on physical capital, could offer a fixed wage and save on wage costs compared to the other divisions.

It is important to keep in mind that we studied stylized incentive contracts in a simple environment. The results are necessarily parameter-dependent. ${ }^{25}$ Also, in repeated settings, workers might learn about the productivity of tournament participants, which might reduce the perceived riskiness of the tournament while at the same time enabling information unraveling. As another example, in an environment where production is subject to strong idiosyncratic shocks, a piece-rate contract may expose workers to more (especially upside) risk than a tournament, diluting or even reversing results on risk sorting. Moreover, as we experimentally varied the available menu of contracts, workers in our setting cannot infer employers' intentions from their contract offer. Workers' interpretations plausibly depend on the available contract options, and differ systematically by personality. We would therefore like to stress that the message of our paper is very much not that a particular type of contract always attracts the same type of workers as long as the contractual environment allows for sufficiently refined sorting patterns. Instead, our findings illustrate that the detailed features of all contractual alternatives available to workers determine the type of workers that are attracted by a particular contract.

\section{Appendix. : Additional tables and figures}

See Tables A1-A4 and Figs. B1-B6.

Table A1

Sorting patterns in different contractual environments, comparison to Dohmen and Falk (2011).

\begin{tabular}{|c|c|c|c|c|}
\hline \multirow[b]{2}{*}{$\begin{array}{l}\text { Contractual environment } \\
\text { Dependent variable }\end{array}$} & \multicolumn{2}{|c|}{ Dohmen and Falk (2011) } & \multicolumn{2}{|l|}{ Present study } \\
\hline & $\begin{array}{l}\text { Menu PF } \\
1=\text { piece rate } \\
(1)\end{array}$ & $\begin{array}{l}\text { Menu TF } \\
1=\text { tournament } \\
\text { (2) }\end{array}$ & $\begin{array}{l}\text { Menu PF } \\
1=\text { piece rate } \\
(3)\end{array}$ & $\begin{array}{l}\text { Menu TF } \\
1=\text { tournament } \\
\text { (4) }\end{array}$ \\
\hline Productivity & $\begin{array}{l}0.027^{\text {wiven }} \\
(0.004)\end{array}$ & $\begin{array}{l}0.011^{n+k} \\
(0.005)\end{array}$ & $\begin{array}{l}0.020^{* * * *} \\
(0.003)\end{array}$ & $\begin{array}{l}0.013^{* * * *} \\
(0.003)\end{array}$ \\
\hline Risk attitude & $\begin{array}{l}0.030^{\text {s.thin }} \\
(0.005)\end{array}$ & $\begin{array}{l}0.060^{\text {think }} \\
(0.020)\end{array}$ & $\begin{array}{l}0.001 \\
(0.014)\end{array}$ & $\begin{array}{l}0.037^{* * * *} \\
(0.012)\end{array}$ \\
\hline Relative self-assessment & $\begin{array}{l}-0.002 \\
(0.009)\end{array}$ & $\begin{array}{l}0.020 \\
(0.013)\end{array}$ & $\begin{array}{l}0.011 \\
(0.006)\end{array}$ & $\begin{array}{l}0.026^{\text {*a*kin}} \\
(0.004)\end{array}$ \\
\hline Female & $\begin{array}{l}-0.012 \\
(0.079)\end{array}$ & $\begin{array}{l}-0.110 \\
(0.073)\end{array}$ & $\begin{array}{l}-0.077 \\
(0.061)\end{array}$ & $\begin{array}{l}-0.026 \\
(0.030)\end{array}$ \\
\hline Observations & 120 & 120 & 288 & 288 \\
\hline Pseudo R-squared & 0.40 & 0.30 & 0.20 & 0.21 \\
\hline
\end{tabular}

Probit estimates, average marginal effects. Standard errors (in parentheses) are clustered on session level. $* * *, * *$ and $*$ denote statistical significance at the $1 \%, 5 \%$ and $10 \%$ level, respectively. Productivity is the number of multiplication problems solved in the 5-minutes work stage before participants make their sorting decision. Risk attitude is the subjectively measured willingness to take risks. Relative self-assessment is an individual's belief about the number of participants he or she outperforms, so that higher values indicate a positive belief about own relative productivity.

*** Denotes statistical significance at the $1 \%$ level.

** Denotes statistical significance at the $5 \%$ level.

* Denotes statistical significance at the $10 \%$ level.

\footnotetext{
${ }^{25}$ For example, if the fixed payment is very low, there is less scope for a decline of average productivity of piece-rate workers in PT compared to $\mathrm{PF}$. Likewise, the higher the loser prize in the tournament, the more low-productive workers are attracted away from the piece-rate contract. If the loser prize in the tournament exceeds the fixed payment, average productivity of piece-rate workers in PT might even rise compared to PF.
} 
Table A2

Sorting patterns in different contractual environments, alternative measures of attitudes towards risk and uncertainty.

\begin{tabular}{|c|c|c|c|c|c|c|}
\hline \multirow[t]{2}{*}{$\begin{array}{l}\text { Contractual environment } \\
\text { Dependent variable }\end{array}$} & \multicolumn{2}{|c|}{$\begin{array}{l}\text { Menu PF } \\
1=\text { piece rate }\end{array}$} & \multicolumn{2}{|c|}{$\begin{array}{l}\text { Menu TF } \\
1=\text { tournament }\end{array}$} & \multicolumn{2}{|c|}{$\begin{array}{l}\text { Menu PT } \\
1=\text { piece rate }\end{array}$} \\
\hline & (1) & (2) & (3) & (4) & (5) & (6) \\
\hline Productivity & $\begin{array}{l}0.018^{\text {*h*x }} \\
(0.002)\end{array}$ & $\begin{array}{l}0.020^{\text {*nktk }} \\
(0.003)\end{array}$ & $\begin{array}{l}0.014^{\text {thex }} \\
(0.003)\end{array}$ & $\begin{array}{l}0.015^{\text {nkwk }} \\
(0.003)\end{array}$ & $\begin{array}{l}0.006^{* * \hbar} \\
(0.003)\end{array}$ & $\begin{array}{l}0.006^{*} \\
(0.003)\end{array}$ \\
\hline Risk attitude: lottery & $\begin{array}{l}0.006 \\
(0.015)\end{array}$ & $\begin{array}{l}-0.006 \\
(0.017)\end{array}$ & $\begin{array}{l}0.037^{\text {tidek }} \\
(0.010)\end{array}$ & $\begin{array}{l}0.044^{\text {ind }} \\
(0.012)\end{array}$ & $\begin{array}{l}-0.056^{* 1 * k+k} \\
(0.011)\end{array}$ & $\begin{array}{l}-0.057^{k * * *} \\
(0.014)\end{array}$ \\
\hline Relative self-assessment & $\begin{array}{l}0.013^{* * x} \\
(0.005)\end{array}$ & $\begin{array}{l}0.011^{*} \\
(0.006)\end{array}$ & $\begin{array}{l}0.020^{* 2 \cdot k x} \\
(0.005)\end{array}$ & $\begin{array}{l}0.020^{* 2 k x} \\
(0.005)\end{array}$ & $\begin{array}{l}-0.021^{* . k \cdot k} \\
(0.006)\end{array}$ & $\begin{array}{l}-0.026^{\text {thex }} \\
(0.006)\end{array}$ \\
\hline Female & $\begin{array}{l}-0.033 \\
(0.063)\end{array}$ & $\begin{array}{l}-0.027 \\
(0.065)\end{array}$ & $\begin{array}{l}-0.026 \\
(0.038)\end{array}$ & $\begin{array}{l}-0.052 \\
(0.057)\end{array}$ & $\begin{array}{l}-0.013 \\
(0.050)\end{array}$ & $\begin{array}{l}0.026 \\
(0.055)\end{array}$ \\
\hline Loss attitude & & $\begin{array}{l}0.013 \\
(0.022)\end{array}$ & & $\begin{array}{l}0.039 \\
(0.016)\end{array}$ & & $\begin{array}{l}-0.027 \\
(0.022)\end{array}$ \\
\hline Ambiguity attitude & & $\begin{array}{l}-0.088 \\
(0.083)\end{array}$ & & $\begin{array}{l}-0.101^{* * *} \\
(0.051)\end{array}$ & & $\begin{array}{l}-0.085 \\
(0.069)\end{array}$ \\
\hline Order effects & yes & yes & yes & yes & yes & yes \\
\hline Additional controls & yes & yes & yes & yes & yes & yes \\
\hline Observations & 270 & 224 & 270 & 224 & 270 & 224 \\
\hline Pseudo R-squared & 0.26 & 0.29 & 0.26 & 0.30 & 0.20 & 0.23 \\
\hline
\end{tabular}

Probit estimates, average marginal effects. Standard errors (in parentheses) are clustered on session level. $* * *, * *$ and $*$ denote statistical significance at the $1 \%, 5 \%$ and $10 \%$ level, respectively. Productivity is the number of multiplication problems solved in the 5-minutes work stage before participants make their sorting decision. Relative self-assessment is an individual's belief about the number of participants he or she outperforms, so that higher values indicate a positive belief about own relative productivity. Risk attitude, loss attitude and ambiguity aversion are measured with incentivized lottery experiments. Higher values of risk, loss, and ambiguity attitudes imply higher tolerance towards risk, losses, and ambiguity, respectively. Additional controls include survey measures of optimism, self-efficacy, competitiveness, and Big-5 personality traits.

$* * *$ Denotes statistical significance at the $1 \%$, level.

** Denotes statistical significance at the 5\% level.

* Denotes statistical significance at the $10 \%$ level.

Table A3

Descriptive statistics by gender.

\begin{tabular}{|c|c|c|c|c|}
\hline & Men & Women & Dif & Overall \\
\hline \multirow[t]{2}{*}{ Productivity } & 23.68 & 20.86 & 2.82 & 22.26 \\
\hline & (11.18) & (8.39) & $\mathrm{P}<0.016$ & (9.96) \\
\hline \multirow[t]{2}{*}{ Relative self-assessment } & 13.91 & 12.54 & 1.36 & 13.22 \\
\hline & (5.26) & (5.09) & $P<0.026$ & $(5.21)$ \\
\hline \multirow[t]{2}{*}{ Risk attitude: subjective } & 6.53 & 5.97 & 0.56 & 6.25 \\
\hline & (1.83) & (1.87) & $\mathrm{p}<0.010$ & (1.87) \\
\hline \multirow[t]{2}{*}{ Risk attitude: lottery } & 7.61 & 6.59 & 1.02 & 7.10 \\
\hline & $(2.28)$ & (2.51) & $P<0.001$ & $(2.44)$ \\
\hline \multirow[t]{2}{*}{ Loss attitude } & 2.25 & 1.99 & 0.26 & 2.12 \\
\hline & $(1.33)$ & $(1.50)$ & $\mathrm{P}<0.120$ & (1.42) \\
\hline \multirow{2}{*}{ Ambiguity attitude } & -0.25 & -0.37 & -0.12 & -0.31 \\
\hline & $(0.45)$ & $(0.54)$ & $P<0.080$ & $(0.50)$ \\
\hline \multirow[t]{2}{*}{ Competitiveness } & 51.20 & 46.51 & 4.69 & 48.84 \\
\hline & (8.89) & (9.27) & $\mathbf{P}<0.000$ & (9.36) \\
\hline \multirow[t]{2}{*}{ Optimism } & 14.95 & 14.68 & 0.28 & 14.81 \\
\hline & $(4.09)$ & (4.17) & $P<0.572$ & (4.12) \\
\hline \multirow{2}{*}{ Self-efficacy } & 32.41 & 30.82 & 1.58 & 31.61 \\
\hline & (5.20) & (5.65) & $P<0.014$ & (5.48) \\
\hline $\mathrm{N}$ & 143 & 145 & & 288 \\
\hline
\end{tabular}

We report means, with standard deviations in parentheses. P-values are two-sided t-tests. Productivity is the number of multiplication problems solved in the 5-minutes work stage before participants make their sorting decision. Relative self-assessment is measured by the question: "how many participants in the experiment do you think are more productive than you are?" Values are inverted, so that they indicate the belief on the number of individuals who are considered to perform worse. Risk attitude (subjective) is measured by the general risk question, where higher values indicate higher willingness to take risks. Risk attitude (lottery) is the number of lotteries preferred over a fixed payment when individuals make a number of choices between a lottery and a fixed payment. Loss attitude likewise measures the number of lotteries preferred over receiving nothing, where the lotteries give a chance on gaining or losing money. Ambiguity attitude measures the willingness to gamble in uncertain situations. Competitiveness is measured as individuals' stated willingness to compete. Optimism is measured using the Revised Life Orientation test. Self-efficacy is measured by use of the New General Self-Efficacy Scale. 
Table A4

Sorting patterns in different contractual environments, including measures of optimism, self-efficacy and competitiveness.

\begin{tabular}{|c|c|c|c|c|c|c|}
\hline \multirow[t]{2}{*}{$\begin{array}{l}\text { Contractual environment } \\
\text { Dependent variable }\end{array}$} & \multicolumn{2}{|c|}{$\begin{array}{l}\text { Menu PF } \\
1=\text { piece rate }\end{array}$} & \multicolumn{2}{|c|}{$\begin{array}{l}\text { Menu TF } \\
1=\text { tournament }\end{array}$} & \multicolumn{2}{|c|}{$\begin{array}{l}\text { Menu PT } \\
1=\text { piece rate }\end{array}$} \\
\hline & (1) & (2) & (3) & (4) & (5) & (6) \\
\hline Productivity & $\begin{array}{l}0.021^{\text {***** }} \\
(0.002)\end{array}$ & $\begin{array}{l}0.019^{\text {*tokt }} \\
(0.003)\end{array}$ & $\begin{array}{l}0.019^{* * \ldots * k} \\
(0.002)\end{array}$ & $\begin{array}{l}0.013^{\text {*t.kek }} \\
(0.003)\end{array}$ & $\begin{array}{l}0.001 \\
(0.003)\end{array}$ & $\begin{array}{l}0.005^{\text {*ik }} \\
(0.002)\end{array}$ \\
\hline Risk attitude & & $\begin{array}{l}-0.007 \\
(0.014)\end{array}$ & & $\begin{array}{l}0.036^{* k x} \\
(0.016)\end{array}$ & & $\begin{array}{l}-0.059^{k * * *} \\
(0.013)\end{array}$ \\
\hline Relative self-assessment & & $\begin{array}{l}0.007 \\
(0.005)\end{array}$ & & $\begin{array}{l}0.023^{\text {ntwex }} \\
(0.006)\end{array}$ & & $\begin{array}{l}-0.021^{\text {1.*k*k}} \\
(0.005)\end{array}$ \\
\hline Female & $\begin{array}{l}-0.043 \\
(0.062)\end{array}$ & $\begin{array}{l}-0.040 \\
(0.060)\end{array}$ & $\begin{array}{l}-0.067 \\
(0.034)\end{array}$ & $\begin{array}{l}-0.052 \\
(0.038)\end{array}$ & $\begin{array}{l}0.066 \\
(0.050)\end{array}$ & $\begin{array}{l}0.052 \\
(0.057)\end{array}$ \\
\hline Optimism & $\begin{array}{l}0.011 \\
(0.009)\end{array}$ & $\begin{array}{l}0.010 \\
(0.009)\end{array}$ & $\begin{array}{l}0.018^{* \ldots+x} \\
(0.008)\end{array}$ & $\begin{array}{l}0.015^{*} \\
(0.008)\end{array}$ & $\begin{array}{l}-0.009 \\
(0.007)\end{array}$ & $\begin{array}{l}-0.006 \\
(0.007)\end{array}$ \\
\hline Self-Efficacy & $\begin{array}{l}0.003 \\
(0.006)\end{array}$ & $\begin{array}{l}0.002 \\
(0.006)\end{array}$ & $\begin{array}{l}0.007^{* *} \\
(0.003)\end{array}$ & $\begin{array}{l}0.006 \\
(0.003)\end{array}$ & $\begin{array}{l}-0.010^{\text {tiket }} \\
(0.004)\end{array}$ & $\begin{array}{l}-0.008^{* . * n+1} \\
(0.003)\end{array}$ \\
\hline Competitiveness & $\begin{array}{l}0.001 \\
(0.003)\end{array}$ & $\begin{array}{l}0.001 \\
(0.003)\end{array}$ & $\begin{array}{l}0.001 \\
(0.003)\end{array}$ & $\begin{array}{l}-0.002 \\
(0.003)\end{array}$ & $\begin{array}{l}-0.008^{* k \hbar} \\
(0.003)\end{array}$ & $\begin{array}{l}-0.004 \\
(0.004)\end{array}$ \\
\hline Order effects & yes & yes & yes & yes & yes & yes \\
\hline Additional controls & yes & yes & yes & yes & yes & yes \\
\hline Wald-test & 0.329 & 0.475 & 0.024 & 0.069 & 0.003 & 0.090 \\
\hline Observations & 288 & 288 & 288 & 288 & 288 & 288 \\
\hline Pseudo R-squared & 0.23 & 0.24 & 0.20 & 0.25 & 0.10 & 0.17 \\
\hline
\end{tabular}

Probit estimates, average marginal effects. Standard errors (in parentheses) are clustered on session level. ${ }^{* * * *},{ }^{* * *}$ and ${ }^{*}$ denote statistical significance at the $1 \%, 5 \%$ and $10 \%$ level, respectively. Productivity is the number of multiplication problems solved in the 5-minutes work stage before participants make their sorting decision. Risk attitude is the subjectively measured willingness to take risks, where higher values indicate higher willingness to take risks. Relative self-assessment is an individual's beliefs about the number of participants he or she outperforms, where higher values indicate a positive belief about own relative productivity. Optimism, Self-Efficacy, and Competitiveness are measured with standardized scales. Additional controls include big-5 personality traits. Wald test reports the p-value of joint significance of Optimism, Self-Efficacy and Competitiveness.

$* * *$ Denotes statistical significance at the $1 \%$ level.

** Denotes statistical significance at the $5 \%$ level.

* Denote statistical significance at the $10 \%$ level.

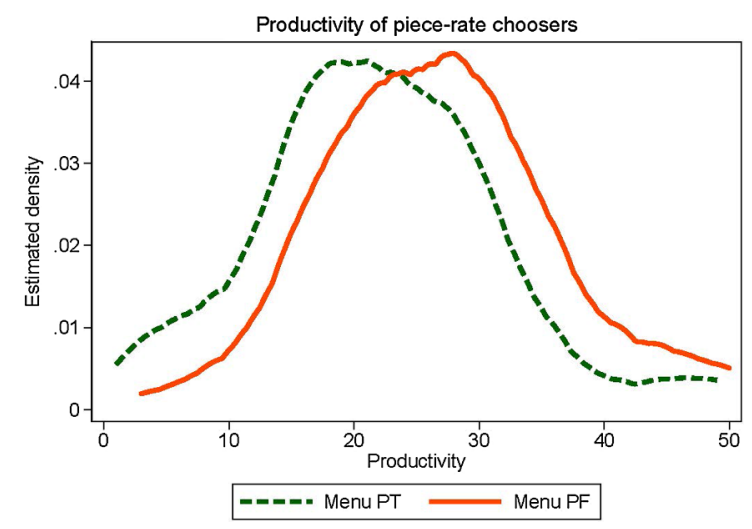

Fig. B1. Productivity differences of workers who choose the piece rate across binary contractual environments. Kernel density plots of productivity by contractual environment. 


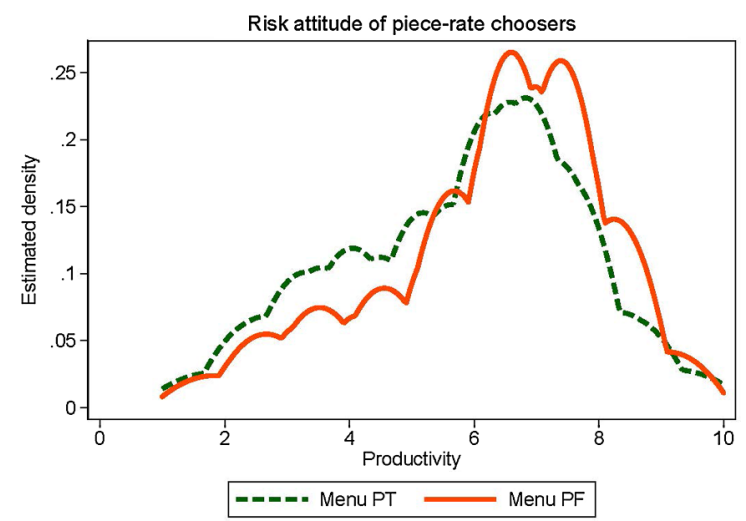

Fig. B2. Risk attitude differences of workers who choose the piece rate across binary contractual environments. Kernel density plots of risk attitudes by contractual environment.

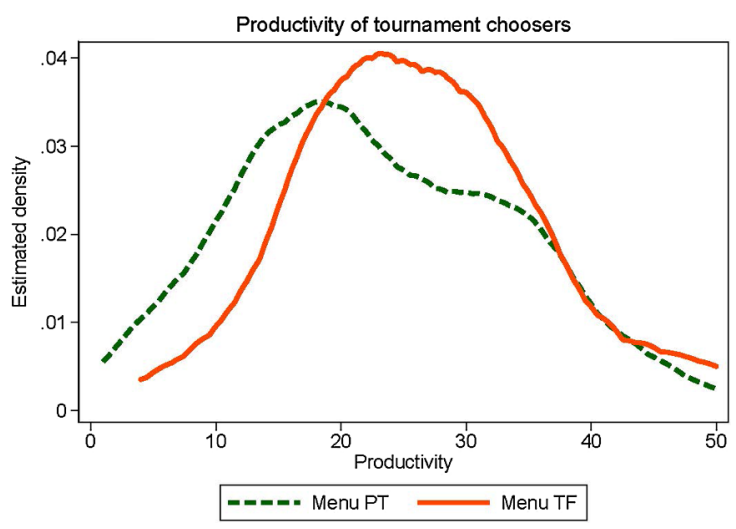

Fig. B3. Productivity differences of workers who choose the tournament across binary contractual environments. Kernel density plots of productivity by contractual environment.

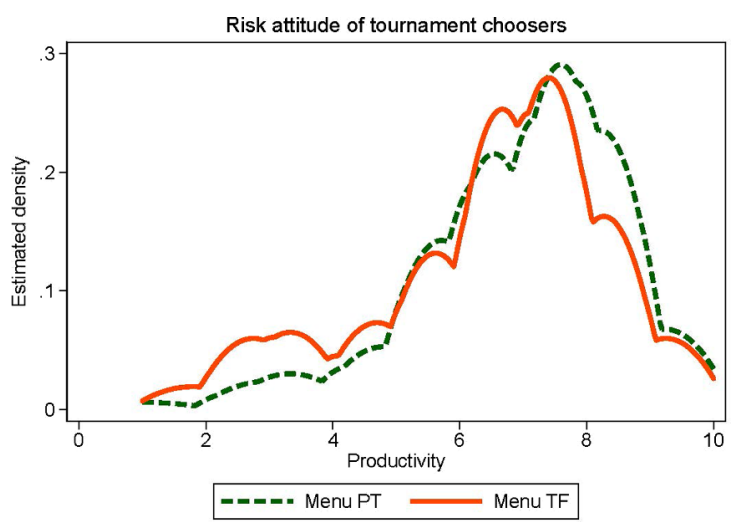

Fig. B4. Risk attitude differences of workers who choose the tournament across binary contractual environments. Kernel density plots of risk attitudes by contractual environment. 


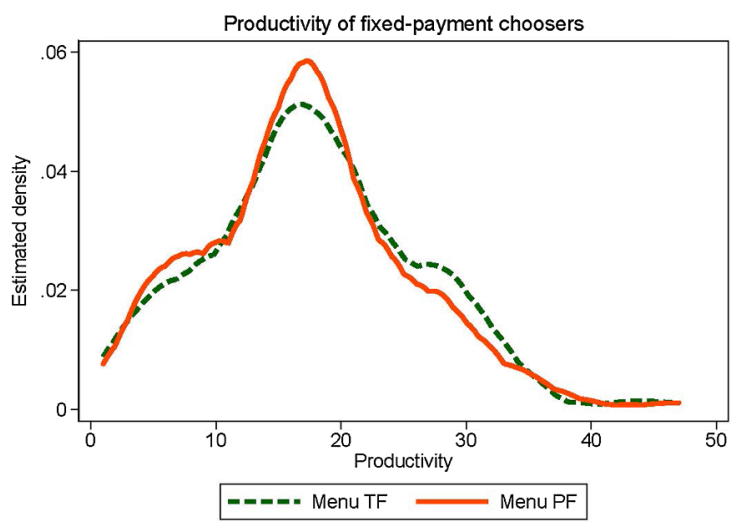

Fig. B5. Productivity differences of workers who choose the fixed payment across binary contractual environments. Kernel density plots of productivity by contractual environment.

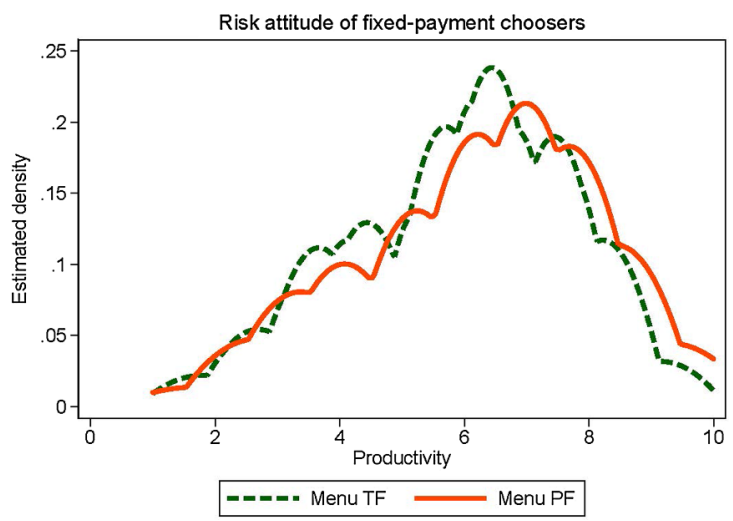

Fig. B6. Risk attitude differences of workers who choose the fixed payment across binary contractual environments. Kernel density plots of risk attitudes by contractual environment.

\section{Appendix A. Supplementary material}

Supplementary data to this article can be found online at https://doi.org/10.1016/j.joep.2019.04.004.

\section{References}

Abdellaoui, M., Baillon, A., Placido, L., \& Wakker, P. P. (2011). The rich domain of uncertainty: Source functions and their experimental implementation. American Economic Review, 101, 695-723.

Bäker, A., \& Mertins, V. (2013). Risk-sorting and preference for team piece rates. Journal of Economic Psychology, 34, $285-300$.

Baron, D. P., \& Besanko, D. (1984). Regulation and information in a continuing relationship. Information Economics and Policy, 1, 447-470.

Barro, J., and Beaulieu, N. (2003) Selection and improvement: Physician responses to financial incentives. Discussion paper. National Bureau of Economic Research. Bellemare, C., \& Shearer, B. (2010). Sorting, incentives and risk preferences: Evidence from a field experiment. Economics Letters, 108(3), 345-348.

Bognanno, M. L. (2001). Corporate tournaments. Journal of Labor Economics, 19(2), 290-315.

Bull, C., Schotter, A., \& Weigelt, K. (1987). Tournaments and piece rates: An experimental study. Journal of Political Economy, 95(1), 1-33.

Cable, D. M., \& Judge, T. A. (1994). Pay preferences and job search decisions: A person-organization fit perspective. Personnel Psychology, 47(2), 317-348.

Cadsby, B. C., Song, F., \& Tapon, F. (2007). Sorting and incentive effects of pay-for-performance: An experimental investigation. The Academy of Management Journal, $50(2), 387-405$.

Chen, G., Gully, S. M., \& Eden, D. (2001). Validation of a new general self-efficacy scale. Organizational Research Methods, 4(1), 62-83.

Chow, C. W. (1983). The effects of job standard tightness and compensation scheme on performance: An exploration of linkages. Accounting Review, 58(4), 667-685. Dohmen, T., \& Falk, A. (2010). You get what you pay for: Incentives and selection in the education system. Economic Journal, 120 (546), F256-F271.

Dohmen, T., \& Falk, A. (2011). Performance pay and multidimensional sorting: Productivity, preferences, and gender. American Economic Review, 101(2), 556-590. Dohmen, T., Falk, A., Huffman, D., Sunde, U., Schupp, J., \& Wagner, G. G. (2011). Individual risk attitudes: Measurement, determinants, and behavioral consequences. Journal of the European Economic Association, 9(3), 522-550.

Eriksson, T., Teyssier, S., \& Villeval, M.-C. (2009). Does self-selection improve the efficiency of tournaments? Economic Inquiry, 47(3), 530-548.

Eriksson, T., \& Villeval, M.-C. (2008). Performance-pay, sorting and social motivation. Journal of Economic Behavior \& Organization, 68(2), $412-421$.

Falk, A., and Fehr, E. (2002). The power and limits of tournaments. unpublished manuscript. University of Zurich.

Farh, J.-L., Griffeth, R. W., \& Balkin, D. B. (1991). Effects of choice of pay plans on satisfaction, goal setting, and performance. Journal of Organizational Behavior, 12(1), $55-62$. 
Fehr, E., \& Goette, L. (2007). Do workers work more when wages are high? Evidence from a randomized field experiment. American Economic Review, 97(1), 298-317. Fischbacher, U. (2007). z-Tree: Zurich toolbox for ready-made economic experiments. Experimental economics, 10(2), $171-178$.

Gerlitz, J.-Y., \& Schupp, J. (2005). Zur Erhebung der Big-Five-basierten Persönlichkeitsmerkmale im SOEP. DIW Research Notes, 4, 1-44.

Gibbons, R. (1987). Piece rate incentive schemes. Journal of Labor Economics, 5(4), 413-429.

Greiner, B. (2004). An online recruitment system for economic experiments. In K. Kremer, \& V. Macho (Vol. Eds.), Forschung und Wissenschaftliches Rechnen. Vol. 63. Forschung und Wissenschaftliches Rechnen (pp. 79-93). GWD Bericht.

Guiteras, R. P., and Jack, B. K. (2014) Incentives, selection and productivity in labor markets: Evidence from rural Malawi, Discussion paper. National Bureau of Economic Research.

Hales, J., Wang, L. W., \& Williamson, M. G. (2014). Selection benefits of stock-based compensation for the rank-and-file. The Accounting Review, 90(4), 1497-1516. Houston, J., Harris, P., McIntire, S., \& Francis, D. (2002). Revising the competitiveness index using factor analysis. Psychological Reports, 90(1), 31-34.

Kachelmeier, S. J., \& Williamson, M. G. (2010). Attracting creativity: The initial and aggregate effects of contract selection on creativity-weighted productivity. The Accounting Review, 85(5), 1669-1691.

Kahneman, D. and Tversky, A. (2013). Prospect theory: An analysis of decision under risk. In: Handbook of the fundamentals of financial decision making: Part I (pp. 99-127).

Kanemoto, Y., \& MacLeod, W. B. (1992). The Ratchet Effect and the market for secondhand workers. Journal of Labor Economics, 10(1), 85-98.

Knoeber, C. R., \& Thurman, W. N. (1994). Testing the theory of tournaments: An empirical analysis of broiler production. Journal of Labor Economics, 12(2), 155-179. Laffont, J.-J., \& Tirole, J. (1988). The Dynamics of Incentive Contracts. Econometrica, 56(5), 1153-1175.

Larkin, I., \& Leider, S. (2012). Incentive schemes, sorting, and behavioral biases of employees: Experimental evidence. American Economic Journal: Microeconomics, $4(2), 184-214$.

Lazear, E. P. (2000). Performance pay and productivity. American Economic Review, 90(5), 1346-1362.

Lazear, E. P., \& Rosen, S. (1981). Rank-order tournaments as optimum labor contracts. Journal of Political Economy, 89(5), 841-864.

Niederle, M., \& Vesterlund, L. (2007). Do women shy away from competition? Do men compete too much? Quarterly Journal of Economics, 122(3), 1067-1101.

Savage, L. J. (1954). The foundations of statistics. New York: Wiley.

Scheier, M. F., Carver, C. S., \& Bridges, M. W. (1994). Distinguishing optimism from neuroticism (and trait anxiety, self-mastery, and self-esteem): A reevaluation of the Life Orientation Test. Journal of Personality and Social Psychology, 67(6), 1063.

Schotter, A., \& Weigelt, K. (1992). Asymmetric tournaments, equal opportunity laws and affirmative action: Some experimental results. Quarterly Journal of Economics, 107(2), 511-539.

Shields, M. D., \& Waller, W. S. (1988). A behavioral study of accounting variables in performance-incentive contracts. Accounting, Organizations and Society, 13(6), 581-594.

Stajkovic, A. D., \& Luthans, F. (2001). Differential effects of incentive motivators on work performance. Academy of Management Journal, 44(3), 580-590.

Stiglitz, J. E. (1975). Incentives, risk, and information: Notes towards a theory of hierarchy. The Bell Journal of Economics, 6(2), 552-579.

Van Dijk, F., Sonnemans, J., \& Van Winden, F. (2001). Incentive systems in a real effort experiment. European Economic Review, 45(2), 187-214.

Waller, W. S., \& Chow, C. W. (1985). The self-selection and effort effects of standard-based employment contracts: A framework and some empirical evidence. Accounting Review, 60(3), 458-476. 